\title{
GU(U)AM - od deklaracji po rzeczywistość
}

Zarys treści: Artykuł ma zadanie nakreślić funkcjonowanie organizacji GUUAM, zrzeszającej od $1997 \mathrm{r}$. Gruzję, Ukrainę, Uzbekistan (oficjalnie wystąpił w 2005) i Mołdawię na szerokim tle toczących się wydarzeń politycznych. Po omówieniu historii powstawania organizacji autorka skupiła się na analizowaniu współpracy w ramach GU(U)AM, kwestii bezpieczeństwa, współzależności energetycznej członków organizacji od Rosji oraz podejmowanej przez GUAM dywersyfikacji surowców i środków transportu. Zastanawiając się, jaka będzie przyszłość tej organizacji, autorka dochodzi do wniosku, że podobnie jak do tej pory uzależniona będzie od polityki bezpieczeństwa energetycznego.

Słowa kluczowe: GU(U)AM, Federacja Rosyjska, Unia Europejska, NATO, bezpieczeństwo energetyczne, TRACEA, INOGATE, SELEC, EPS, Europejska Polityka Sąsiedztwa

Key words: GUAM, UE, energy security, Organization for Democracy and Economic Development, Transport Corridor Europe-Caucasus-Asia, Intrastate Oil Gas Transport to Europe, Southeast European Law Enforcement Center

\section{Z historii organizacji}

Rozpad ZSRR w 1991 r. dał początek kilkunastu suwerennym państwom, dla których szansą na uwolnienie się spod dominacji Federacji Rosyjskiej (FR), która nadal kontynuowała swoją imperialną politykę, była współpraca regionalna. Wydawała się ona jedynym wyjściem wobec podejścia Rosji do powstałej Wspólnoty Niepodległych Państw, wobec której przyjęto model „centrum - peryferie”, gdzie peryferie rozpatrywano jako: rynek zbytu mało konkurencyjnej produkcji; źródło tanich surowców; operacyjne lub strategiczne przedpole obronne ${ }^{1}$. W 1994 r. prezydent Gruzji

\footnotetext{
${ }^{1}$ Za takim modelem optowano już w styczniu 1993 roku. K. Malak, Polityka zagraniczna Rosji w okresie prezydentury Borysa Jelcyna (1991-2000), [w:] P. Kraszewski (red.), Cywilizacja Rosji imperialnej, Poznań 2002, s. 327.
} 
Eduard Szewardnadze wystąpił z inicjatywą utworzenia organizacji regionalnej, podkreślając konieczność integracji krajów z regionu Kaukazu i Azji Centralnej ze światowym systemem ekonomicznym. W przypadku Azerbejdżanu, Gruzji, Mołdawii ${ }^{2}$ i Ukrainy za początek współpracy można uznać wiedeński szczyt konferencji w sprawie traktatu o siłach konwencjonalnych w Europie w 1996 roku. Cztery wymienione wyżej kraje ogłosiły zgodne stanowisko i zaproponowały wspólne inicjatywy. Na posiedzeniu Rady Europy 10 X 1997 r. w Strasburgu prezydenci Azerbejdżanu, Gruzji, Mołdawii i Ukrainy określili wspólne interesy i chęć rozwijania wzajemnych stosunków w dziedzinie politycznej, ekonomicznej i militarnej. Podkreślano perspektywy kooperacji w ramach OBWE i innych struktur europejskich i atlantyckich. Nowa inicjatywa w formie forum konsultacyjnego otrzymała nazwę od pierwszych liter nazw krajów go tworzących. Miała być organizacją opartą na wspólnocie interesów gospodarczych ${ }^{3}$. Po konsultacjach ministrów spraw zagranicznych doszło w listopadzie 1997 r. do podpisania wspólnego protokołu, który określił zakres działań grupy. Współpraca miała obejmować współdziałanie w sferze politycznej, na polu pokojowego rozwiązywania konfliktów, w dziedzinie zwalczania separatyzmu, w celu intensyfikacji działań w ramach TRACECA ${ }^{4}$, integracji ze strukturami europejskimi i euroatlantyckimi. Deklaracje te, poszerzone o chęć współpracy w ramach budowy gazociągu kaspijskiego, zostały powtórzone w październiku 1998 r. w Waszyngtonie. Dwa miesiące później państwa GUAM zadeklarowały chęć współpracy z ONZ i NATO 5 .

Wpływ na decyzję o powołaniu GUAM miała coraz większa aktywność integracyjna Rosji na terenie Wspólnoty Niepodległych Państw (WNP) przejawiająca się w podpisywaniu kolejnych układów integrujących Białoruś z Rosją (efektem stał się Związek Białorusi i Rosji - ZBiR). Grupa GUAM od momentu powstania postrzegana była na Zachodzie jako instytucja o antyrosyjskim zabarwieniu. Tak omawiał to analityk Robert Larsson w pracy Georgia's Search for Security ${ }^{6}$. Podobnie widział to Kreml. W późniejszym czasie Konstanty Zatulin, dyrektor moskiewskiego instytutu krajów WNP i poseł do Dumy, sformułował to w następujących

${ }^{2}$ Bardzo często stosowana jest nazwa Mołdowa, a w kontaktach dyplomatycznych Republika Mołdowy, mimo że Komisja Standaryzacji Nazw Geograficznych poza granicami RP zaleca wyłącznie formy Mołdawia i Republika Mołdawii.

3 Ł. Wróblewski, GUAM-Organizacja na rzecz Demokracji i Rozwoju, http://www.psz.pl/index2. php?option=content\&do_pdf=18id=2907 (dostęp 5 II 2012).

4 TRACECA (Transport Corridor Europe-Caucasus-Asia) - korytarz transportowy Europa-Kaukaz-Azja. Docelowo sieć TRACECA zostanie połączona z siecią transeuropejską TEN (Trans-European-Networks), z którą ma się złączyć w Turcji, Rumunii i na Ukrainie, tworząc tym samym nowy międzykontynentalny szlak komunikacyjny, J. Brodowski, Wzajemne relacje Federacji Rosyjskiej i Azerbejdżanu w ramach WNP, [w:] E. Cziomer, M. Czajkowski (red.), Polityka Federacji Rosyjskiej wobec państw członkowskich WNP, Kraków 2006, s. 97.

5 A. Myśliwy, GUUAM - szansa na stabilizację dla „Eurazjatyckich Bałkanów”, „Arcana” 2005, nr 3, s. 134.

${ }^{6}$ http://pdc.ceu.hu/archive/00004538/01/Robert_Larson_Georgia_Search_for_Security.pdf, s. 56-57 (dostęp 2 II 2012). 
słowach: „Po rozbiciu Jugosławii Zachód zabrał się do niszczenia Wspólnoty Niepodległych Państw. Służyć temu ma właśnie GUAM - organizacja wspierana finansowo przez Stany Zjednoczone tylko po to, by osłabić WNP"7. Organizacja postrzegana jest przez FR jako zagrożenie dla monopolu rosyjskiego w dziedzinie przesyłania surowców energetycznych, za czynnik decentralizujący WNP i za przyczółek amerykański na obszarze byłego ZSRR ${ }^{8}$. Od początku GUAM działał dzięki politycznemu i finansowemu wsparciu Stanów Zjednoczonych zainteresowanych rozwojem współpracy energetycznej z państwami regionu Morza Kaspijskiego ${ }^{9}$. Mimo oficjalnych zapewnień składanych przez różnych członków GUAM, że nie jest to organizacja wymierzona przeciwko Rosji, w jej celach i zadaniach - jak chociażby walka z separatyzmami (które Rosja wspiera) - nietrudno dopatrzeć się „antyrosyjskich elementów”. Uzależnienie energetyczne od Rosji wszystkich państwa członkowskich daje możliwość wywierania wpływu na politykę wewnętrzną i zewnętrzną republik.Ważny dla krajów tworzących GUAM okazał się rok 1999. W styczniu w Baku spotkali się ministrowie obrony krajów GUAM w celu omówienia spraw dotyczących polityki bezpieczeństwa ${ }^{10}$. Rosja zakończyła wycofywanie wojsk z granicy gruzińsko-tureckiej, a pod naciskiem Zachodu na szczycie OBWE w Stambule zadeklarowała wycofanie wszystkich oddziałów z terytorium Gruzji. Gruzja, Azerbejdżan i Uzbekistan 2 kwietnia nie przedłużyły udziału w układzie taszkienckim i przestały być częścią zdominowanego przez Rosję sojuszu obronnego. W kwietniu 1999 r. do GUAM dołączył Uzbekistan, który od początku silnie akcentował chęć udziału tylko w inicjatywach ekonomicznych, odżegnując się od współpracy wojskowej i politycznej ${ }^{11}$. Podczas szczytu NATO - Rada Partnerstwa Północnoatlantyckiego w Waszyngtonie 24 kwietnia 1999 r. zmieniono nazwę organizacji na GUUAM. W przyjętej deklaracji wyrażono potrzebę intensyfikacji wielostronnej współpracy, koordynacji polityki na forum międzynarodowych instytucji, wzmocnienia współdziałania w ramach Partnerstwa dla Pokoju i Rady Partnerstwa

${ }^{7}$ Cyt. za M. Przełomiec, Grajmy w GUAM, „OZON”, nr 22 (59) 2006, s. 50. Więcej na temat roli USA w inicjatywie integracyjnej GU(U)AM zob. P. Goble, The United States and GUAM: From Tactic to Partnership, „Central Asia and the Caucasus”, 2008, no. 3-4, s. 156-160.

${ }^{8}$ A. Dugin - jeden z najbardziej znanych zwolenników neoeurazjatyzmu - uważa, że w przestrzeni postradzieckiej trwa walka o dominację pomiędzy dwoma cywilizacjami - kontynentalną (Rosja) oraz oceaniczną (USA i zwolennicy). Powstanie GUUAM i wspieranie przez świat zachodni tzw. „kolorowych rewolucji” ma prowadzić do przejęcia władzy w państwach postradzieckich przez elity niechętnie nastawione do działań Rosji w przestrzeni WNP. Według niego terytoria państw GUUAM stają się obszarem obecności strategicznej USA i NATO, R. Mazur, Wspólnota Niepodległych Państw - integracja czy dezintegracja, [w:] Z. J. Winnicki, W. Baluk, G. Tokarz (red.), Wybrane problemy badań wschodnich, Wrocław 2007, s. 181-182. Tu i w następnym przywoływanym artykule (przypis 12) występuje zbieżność imienia i nazwiska Autorki przytaczanych prac.

9 E. Wyciszkiewicz, Perspektywy rozwoju GUUAM, „Biuletyn Polskiego Instytutu Spraw Międzynarodowych" nr 31(276), 25 kwietnia 2005, s. 1393, http://www.pism.pl/files/?id_plik=214 (dostęp 21 II 2012).

10 A. Myśliwy, op. cit., s. 134.

11 Ibidem. 
Północnoatlantyckiego oraz aktywizacji pokojowego rozwiązywania sporów. Podjęto decyzję o prewencji przemytu broni na obszary konfliktów. Przyjęto wspólne stanowisko w kwestii rozszerzenia i przyspieszenia prac nad korytarzem transportowym Europa-Kaukaz-Azja (zwanym Jedwabnym Szlakiem XXI wieku), będącego projektem $\mathrm{UE}^{12}$. W kwietniu tego roku ruszył transport ropy z Azerbejdżanu do gruzińskiego wybrzeża Morza Czarnego rurociągiem Baku-Supsa, zbudowanym przez firmy zachodnie ${ }^{13}$.

Państwa członkowskie poprzez GUUAM chciały wzmocnić nacisk na Unię Europejską (UE) i NATO w sprawie zwiększenia swojej obecności w regionie, aby ograniczyć znaczenie Rosji. Atutem porozumienia miało być to, że jego członkowie należeli do różnych subregionów geopolitycznych. Przeszłość sowiecka też była w pewnym stopniu zaletą - państwa te posiadają podobną i wzajemnie kompatybilną infrastrukturę (sieci drogowe, kolejowe, wykorzystywane pojazdy, park maszynowy i technologiczny), co ułatwia wymianę handlową i nadaje całemu układowi charakter spójnego obszaru gospodarczego ${ }^{14}$. Gruzję, Azerbejdżan i Mołdawię łączy walka z separatyzmami w Południowej Osetii, Abchazji, Górskim Karabachu i Naddniestrzu oraz dążenie do przywrócenia integralności terytorialnej. Dla Gruzji, dla której w grudniu 2000 r. Rosja wprowadziła wizy, co w konsekwencji doprowadziło jej gospodarkę na skraj kryzysu, dążenie do budowania ścisłej współpracy regionalnej stawało się coraz istotniejsze.

Ponieważ działalność w ramach GUUAM postrzegana była jako mało efektywna, na szczycie ONZ w Nowym Jorku we wrześniu 2000 r. członkowie GUUAM zadecydowali o pogłębieniu współpracy w ramach stworzonej organizacji. Rozwijaniu kontaktów miały służyć organizowane w formie „szczytów” regularnie spotkania głów państw (przynajmniej raz do roku) oraz ministrów spraw zagranicznych (dwa razy w roku). Zapowiedziano powołanie Komitetu Narodowych Koordynatorów, który miał odbywać sesje co kwartał i być odpowiedzialny za koordynację współpracy. Przyjęto zasadę konsensusu przy podejmowaniu decyzji. Oświadczono, że organizacja jest otwarta na wszystkie państwa uznające i przestrzegające jej zasad. Rozmowy skoncentrowane były głównie na zagadnieniach promocji międzynarodowego handlu i transportu, rozwiązywaniu konfliktów lokalnych oraz powiększeniu grupy (dyskusja dotyczyła Polski, Słowacji, Rumunii i Bułgarii). Rozpoczęły się negocjacje na temat utworzenia strefy wolnocłowej. Zobowiązano się do uregulowa-

12 A. Lemieszonek, GUAM-integracja ale bez udziału Rosji. Wzloty i upadki instytucjonalnej wspótpracy państw byłego ZSRR,http://www.stosunkimiedzynarodowe.pl/guam-integracja-ale-bez-udziałurosji-wzloty-i-upadki-instytucjonalnej-współpracy-państw-byłego-zsrr (dostęp 21 II 2012); R. Mazur, GUUAM, [w:] T. Łoś-Nowak (red.), Organizacje w stosunkach międzynarodowych. Istota-mechanizmy działania-zasięg, Wrocław 2004, s. 256-257.

${ }^{13}$ W niedługim czasie rządy Azerbejdżanu, Gruzji i Turcji podpisały umowę o budowie ropociągu Baku-Tbilisi-Ceyhan, P. Trzaskowski, Kulturowe źródła prozachodniej polityki zagranicznej Gruzji, [w:] P. Adamczewski (red.), Konflikty na obszarze byłego ZSRR, Poznań 2009, s. 194-195.

${ }_{14}$ J. Siekierzyński, Historia i rola układu GUUAM we wspótczesnej polityce Eurazjatyckiej, [w:] A. Furier (red.), Kaukaz w dobie globalizacji, Poznań 2005, s. 64. 
nia w przyszłości kwestii ruchu bezwizowego na mocy porozumień bilateralnych. Stany Zjednoczone obiecały pomoc, wsparcie i nakłady finansowe na poszczególne projekty GUUAM ${ }^{15}$.

Szczególne znaczenie dla rozwoju organizacji miał szczyt w Jałcie (6-7 czerwca 2001), na którym sformułowano Kartę GUUAM, przekształcając regionalną organizację w międzynarodową. Karta GUUAM składa się z ośmiu artykułów. Cele GUUAM określono w artykule I - są nimi: wspieranie rozwoju gospodarczego i społecznego, wzmacnianie i rozszerzenie handlu i powiązań gospodarczych (w tym utworzenie Wolnej Strefy Handlowej GUUAM), rozwój i efektywne wykorzystanie w interesie GUUAM transportu i infrastruktury komunikacyjnej, wzmocnienie regionalnego bezpieczeństwa we wszystkich sferach działalności, rozwijanie stosunków w dziedzinie nauki i kultury oraz w sferze humanitarnej, współpraca na forum organizacji międzynarodowych, walka $\mathrm{z}$ międzynarodowym terroryzmem, zorganizowaną przestępczością i handlem narkotykami, współpraca w organizacjach międzynarodowych, umocnienie współpracy z UE i NATO. Główne kierunki współpracy GUUAM to: gospodarka, nauka, technologia i środowisko, transport, energia, infrastruktura telekomunikacyjna, wspólne projekty inwestycyjne i finansowe, kultura, edukacja, środki masowego przekazu, turystyka, wymiana młodzieży. Zgodnie z Kartą głównym organem GUUAM są coroczne spotkania szefów państw - wtedy właśnie zapadają decyzje w sprawie głównych kierunków działania GUUAM. Każde z państw członkowskich ma stać na czele prezydencji przez rok. O kolejności jej sprawowania decyduje alfabet. Organem wykonawczym GUUAM jest Rada Ministrów Spraw Zagranicznych. Spotkania Rady odbywają się co pół roku, a ich zadaniem jest wdrożenie postanowień przyjętych przez członków oraz przygotowanie propozycji w dziedzinie rozwoju i współpracy na najbliższy szczyt prezydentów GUUAM. Powstały specjalistyczne komitety złożone z ministrów poszczególnych resortów. Oficjalnym ośrodkiem prasowym GUUAM zostało MSZ Ukrainy. Ponieważ Mołdawia sprzeciwiła się podpisaniu Karty GUUAM, została ona przekazana międzynarodowym koordynatorom w celu przeredagowania. W odpowiedzi na wydarzenia, które nastąpiły w Jałcie, rosyjskie MSZ wydało memorandum, w którym wyraziło potępienie wobec państw GUUAM za odejście od początkowego charakteru stowarzyszenia jako nieformalnego forum konsolidacyjnego, zmianę doktryny polityki energetycznej i forsowanie idei współpracy wojskowej ${ }^{16}$.

Na szczycie w Jałcie 19-20 VII 2002 r. ${ }^{17}$ zostały określone szczegółowe kompetencje Rady Ministrów Spraw Zagranicznych. Zadania Rady zostały uzupełnione o działania na rzecz rozwoju współpracy, w tym w dziedzinie dyplomacji. Rada przygotowuje wspólne stanowiska państw GUUAM w kwestiach międzynarodowych i kontaktach zewnętrznych. Przygotowywaniem spotkań szefów państw i spotkań

15 A. Lemieszonek, op. cit.; A. Myśliwy, op. cit., s. 135.

16 A. Lemieszonek, op. cit.; R. Mazur, op. cit., s. 257; A. Myśliwy, op. cit., s.135-138.

$17 \mathrm{~W}$ konferencji jako obserwatorzy uczestniczyli przedstawiciele pięciu państw europejskich, USA i dziesięciu organizacji międzynarodowych. 
Rady zajmuje się Komitet Koordynatorów Narodowych, w którego skład wchodzi jeden przedstawiciel z każdego państwa, mianowany przez ministra spraw zagranicznych. Komitet spotyka się co kwartał, ale może się też spotkać poza wyznaczonym terminem na prośbę jednego z członków. Przewidziano regularne spotkania ministrów spraw zagranicznych, obrony, przemysłu naftowego oraz ekspertów. W celu realizacji porozumień handlowych utworzono Radę Gospodarczą, której zadaniem ma być aktywizacja współpracy gospodarczej, stwarzanie warunków do rozwoju wielostronnej współpracy w sferze transportu i energetyki oraz sprzyjanie integracji państw członkowskich z gospodarką światową. Podpisano porozumienie o strefie wolnego handlu. Zadecydowano o powołaniu Biura Informacyjnego z siedzibą w Kijowie. Pod wpływem wydarzeń z 11 IX 2001 r. przyjęto porozumienie o walce $\mathrm{z}$ terroryzmem międzynarodowym i przestępczością zorganizowaną. Podkreślono determinację krajów członkowskich $w$ dążeniu do zapewnienia politycznej, prawnej i organizacyjnej podstawy dla wyzwań w postaci separatyzmów, nietolerancji i ekstremizmu. W szczycie nie wziął udziału prezydent Uzbekistanu, gdyż miesiąc wcześniej tamtejszy MSZ poinformował o zawieszeniu uczestnictwa w organizacji. Rosyjskie media przyjęły tę wiadomość z radością, komentując, że jest to „koniec wirtualnego dziwoląga” jakim był GUUAM ${ }^{18}$.Kolejny szczyt GUUAM został zorganizowany w Jałcie 3-4 VII 2003 roku. Niestety, odbył się on w bardzo okrojonym składzie, nie pojawili się bowiem prezydenci Azerbejdżanu, Uzbekistanu i Mołdawii (wszyscy tłumaczyli się złym stanem zdrowia). Niezwykle pokaźne było za to grono obserwatorów - 29 wysłanników państw i organizacji międzynarodowych. Podjęto decyzję o utworzeniu Zgromadzenia Parlamentarnego GUUAM $^{19}$. Powołano do życia Radę Reprezentantów Prezydenckich do spraw Rozwoju Transportu Ropy. W ramach współpracy GUUAM-USA zadecydowano o ustanowieniu Wirtualnego Centrum GUUAM do spraw zwalczania terroryzmu, przestępczości zorganizowanej, handlu narkotykami i innych form niebezpiecznych przestępstw oraz o utworzeniu Międzynarodowego Centrum Informatyczno-Analitycznego. Ostatnia wspólna inicjatywa GUUAM i USA dotyczyła szkolenia jednostek antyterrorystycznych w celu ochrony rurociągów i zwalczania terroryzmu ${ }^{20}$.

W październiku 2003 r. organizacji GUUAM został przyznany status obserwatora w Zgromadzeniu Ogólnym ONZ. W tym samym czasie status ten został również przyznany związanej z Federacją Rosyjską Euroazjatyckiej Wspólnocie Gospodarczej.

18 A. Myśliwy, op. cit., s. 136; A. Lemieszonek, op. cit.; Przemówienie Prezydenta Republiki Azerbejdżanu Hajdara Alijewa na szczycie jałtańskich przywódców państw krajów członkowskich GUUAM, 20 lipca 2002 roku, http://lib.aliyev-heritage.org/pl/3417868.html (dostęp 5 II 2012); P. Andrusieczko, Perspektywy alternatywnych organizacji regionalnych na przykładzie GUAM, [w:] T. Kapuśniak (red.), Wspólnota niepodległych państw: fragmegracja-bezpieczeństwo-konflikty etniczne, Lublin-Warszawa 2011, s. 46.

19 Porozumienie o utworzeniu Zgromadzenia Parlamentarnego Państw GUUAM zostało przyjęte 24 września 2004 r. w Kijowie. Jedynym państwem, które go nie podpisało był Uzbekistan. A. Myśliwy, op. cit., nr 3, s. 139.

${ }^{20}$ Ibidem, s. 136-137; A. Lemieszonek, op. cit.; Ł. Wróblewski, op. cit. 
Kolejny szczyt GUUAM miał się odbyć w Batumi 16 VI 2004. Tuż przed spotkaniem prezydent Mołdawii Władimir Woronin poprosił o zmianę miejsca $\mathrm{z}$ powodu niestabilnej sytuacji w Adżarii. Brakiem czasu tłumaczył się prezydent Islam Karimow. $\mathrm{Z}$ powodu niemożności porozumienia między prezydentami spotkanie zostało odłożone na inny, bliżej nieokreślony termin ${ }^{21}$.

Dyskusje o konieczności odbycia zaległego szczytu rozpoczął w marcu 2005 r. W. Woronin. Jego zabiegi w celu wskrzeszenia GUUAM były odbierane jako hasło przedwyborcze $\mathrm{w}$ celu zapewnienia zwycięstwa partii komunistycznej w nadchodzących wyborach parlamentarnych. Prologiem do szczytu było spotkanie w pierwszych dniach marca 2005 r. Władimira Woronina, Wiktora Juszczenki i Micheil’a Saakaszwilego. Prezydenci Gruzji i Mołdawii podpisali układ nazwany „Mapą czarnych dziur”, w którym przewidywano uregulowanie sytuacji w Abchazji, Południowej Osetii i Naddniestrzu m.in. przez zażądanie od FR wycofania jej wojsk $\mathrm{z}$ tych terytoriów ${ }^{22}$.

Podkreślić należy, że wszyscy członkowie GUUAM pozostali nadal w składzie $\mathrm{WNP}^{23}$, ugrupowania, które przez analityków postrzegane jest jako instrument integracji państw tworzących Wspólnotę i służyć ma polityce bezpieczeństwa Rosji, zwłaszcza w przyległej strefie Kaukazu i Azji Środkowej ${ }^{24}$. Po „pomarańczowej rewolucji” władze w Kijowie oficjalnie przyznawały, że WNP powołana kiedyś w celu osłabienia skutków rozpadu ZSRR spełniła już swoją rolę i w obecnej formie, jako organizacja zdecydowanie podporządkowana Rosji, traci rację bytu ${ }^{25}$. Zmiana sytuacji politycznej i wydarzenia 2008 r. pokazały, że rzecz ma się inaczej. Po wystąpieniu Gruzji z WNP, którego procedura ostatecznie zakończyła się 18 VIII 2009, prezydenci Ukrainy, Azerbejdżanu i Mołdawii wzięli udział w kiszyniowskim szczycie WNP (8-9 X 2009). Gruzja zaś utrzymała w mocy 75 umów międzynarodowych, które ma zawarte z członkami WNP26.

W styczniu 2005 r. w Kiszyniowie odbyło się spotkanie narodowych koordynatorów GUUAM, na które oprócz państw członkowskich przyjechali przedstawiciele Departamentu Stanu USA oraz ambasad Polski, Rumunii, Turcji i Bułgarii. Rozmowy dotyczyły współpracy regionalnej. Na konferencji prasowej kończącej spotkanie w Kiszyniowie minister spraw zagranicznych Mołdawii oświadczył jednak, że działalność GUUAM nie jest skierowana przeciwko Rosji. Ma on na celu rozwiązywanie własnych problemów politycznych i gospodarczych i umacnianie

${ }^{21}$ A. Myśliwy, op. cit., s. 137, 139.

${ }^{22}$ Ibidem, s. 137.

${ }^{23}$ Ukraina nie podpisała Statutu WNP i formalnie nie jest członkiem, a jedynie założycielem i uczestnikiem.

${ }^{24}$ M. E. Szatlach, Porozumienie regionalne w globalnym systemie bezpieczeństwa, [w:] J. Knopek, D. J. Mierzejewski (red.), Bezpieczeństwo narodowe i regionalne w procesach globalizacji, Piła 2006, s. $103-104$.

25 M. Przełomiec, op. cit., s. 50.

${ }^{26}$ M. Banaszkiewicz, Kiszyniowski szczyt WNP w odbiorze rosyjskim, „Biuletyn Międzynarodowy”, t. II (2010), s. 207-208. 
bezpieczeństwa $\mathrm{w}$ regionie i nie jest alternatywą wobec $\mathrm{WNP}^{27}$. Oświadczenie to pokazało, że państwa GUUAM najchętniej prowadziłyby politykę zacieśniania więzi z krajami spoza WNP, przy jednoczesnym zapewnieniu Rosji o swej lojalności bądź nieszkodliwości.

GUUAM był również jednym $\mathrm{z}$ tematów późniejszych rozmów W. Juszczenki z premierem Gruzji Zurabem Nogaideli. Prezydent Ukrainy zaproponował, aby „działalność organizacji wypełnić realną treścią"28.

Reaktywacją organizacji miał być szczyt w Kiszyniowie 22 IV 2005 r., na który przybyli prezydenci państw członkowskich, z wyjątkiem prezydenta Uzbekistanu, prezydenci Litwy i Rumunii oraz przedstawiciel amerykańskiego Departamentu $\mathrm{Stanu}^{29}$. Według prezydenta Gruzji M. Saakaszwilego rozpoczyna się trzecia fala rewolucji w republikach postradzieckich i należy wykorzystać nową sytuację w celu przypisania współpracy państw członkowskich nowego wymiaru. Głównym postulatem było nadanie luźnemu dotąd stowarzyszeniu struktury sprawnie działającej organizacji. Szefowie państw - członków GUAM ogłosili Deklarację o stabilności i rozwoju, w której potwierdzili dążenia ich państw do integracji europejskiej i euroatlantyckiej, przywiązanie do zasad demokracji i wartości europejskich oraz wyrazili zaniepokojenie zagrożeniami dla bezpieczeństwa ze strony terroryzmu międzynarodowego i agresywnego separatyzmu. Za nowy kierunek współpracy postawiono sobie dążenie do uregulowania zamrożonych konfliktów na obszarze poradzieckim ${ }^{30}$. Strona ukraińska wystąpiła z propozycją zawarcia sojuszu, który przeciwstawiłby się zagrożeniom związanym z separatyzmem. Organizacja zamierza występować na forum międzynarodowym w celu uzyskania poparcia dla swoich planów przywrócenia integralności terytorialnej (Osetia Południowa i Abchazja do Gruzji, Górski Karabach do Azerbejdżanu i Naddniestrze do Mołdawii). Opowiedziano się za bliską współpracą polityczno-wojskową, w tym inicjowaniem wspólnych misji pokojowych z mandatem ONZ i OBWE ${ }^{31}$.

Podczas szczytu Gruzja i Mołdawia żądały wycofania ze swoich terytoriów wojsk rosyjskich. Prezydent Ukrainy W. Juszczenko w Kiszyniowie wyszedł z propozycją uregulowania konfliktu naddniestrzańskiego ${ }^{32}$ za pomocą tzw. siedmiu kroków:

27 V. Dunaeva, Razem, ale z kim?, „Nowe Państwo” 2005, nr 6, s. 78-79.

28 A. Myśliwy, op. cit., s. 140.

${ }^{29}$ Mimo zaproszeń nie przybyli prezydenci Polski, Węgier i Bułgarii.

${ }^{30}$ A. Lemieszonek, op. cit.; Ł. Wróblewski, op. cit.

31 E. Wyciszkiewicz, op. cit.

32 Sytuacja na naddniestrzańskim odcinku granicy z Ukrainą bardzo się zaostrzyła po $2001 \mathrm{r}$. i po zmianach regulacji w zakresie transportu międzynarodowego w Naddniestrzu. Mołdawia zmieniła ustawodawstwo celne i podatkowe, co w konsekwencji doprowadziło do blokady ekonomicznej. W odpowiedzi Naddniestrze wprowadziło $20 \%$ cło na mołdawskie towary, podjęło specjalną kontrolę migracyjną podczas przekraczania granicy i ustanowiło opłatę za jej przekraczanie. Rząd naddniestrzański podjął kroki, które doprowadziły do zamknięcia własnego rynku dla mołdawskich produktów - wprowadzono $100 \%$ cło na mołdawskie produkty. Szerzej na ten temat: N. Cwicinskaia, Gospodarka Naddniestrza i je powiąania z gospodarka Mołdowy, [w:] P. Adamczewski (red.), op. cit., s. 157-162. 
- stworzenie przez administrację Naddniestrza warunków dla rozwoju społeczeństwa obywatelskiego,

- stworzenie przez administrację Naddniestrza warunków dla rozwoju systemu wielopartyjnego,

- przeprowadzenie w Naddniestrzu pod kontrolą obserwatorów z UE, OBWE, Ukrainy, Rosji i USA demokratycznych wyborów do Rady Najwyższej (miała pełnić rolę parlamentu),

- przekształcenie sił pokojowych w międzynarodowy mechanizm i rozszerzenie ilościowego składu ukraińskich sił pokojowych,

- dopuszczenie ukraińskich specjalistów do monitoringu wojenno-przemysłowego kompleksu Naddniestrza,

- stworzenie grupy monitoringu w składzie OBWE i innych międzynarodowych organizacji dla kontroli nad tranzytem ładunków na odcinku granicy naddniestrzańsko-ukraińskiej,

- poparcie przez Ukrainę Stanów Zjednoczonych i UE w ich działaniach na rzecz uregulowania naddniestrzańskiego konfliktu ${ }^{33}$.

Ponieważ propozycja nie była wcześniej uzgodniona $\mathrm{z}$ władzami Mołdawii, nie można jej było przedstawić jako wspólnego stanowiska GUUAM. Była jednak dobitnym podkreśleniem faktu, że to Ukraina była od początku liderem w tym regionalnym stowarzyszeniu. Propozycje przedstawione na szczycie GUUAM w Kiszyniowie zostały dopracowane w tzw. planie Juszczenki ${ }^{34}$. Sprowadzało się to do demokratyzacji regionu naddniestrzańskiego. Wybrana w demokratycznych wyborach Rada Naczelna miała zostać uznana przez Kiszyniów za organ prawnego przedstawicielstwa Naddniestrza i miała prowadzić negocjacje z władzami mołdawskimi o podział kompetencji. Uregulowaniem konfliktu miało być podpisanie umowy (wspólnie z Ukrainą, Rosją i OBWE) o gwarancjach przestrzegania przez Republikę Mołdawii specjalnego prawnego statusu Naddniestrza. Plan Juszczenki, mimo pewnych zasadniczych uwag, został zaakceptowany. Krytykowano go jednak głównie za brak poruszenia kwestii wycofania z regionu uzbrojenia FR. Kwestia wyprowadzenia wojsk rosyjskich i ustanowienie należytej kontroli na odcinku naddniestrzańskim granicy mołdawsko-ukraińskiej była podnoszona szczególnie przez Republikę Mołdawii ${ }^{35}$. Jednak wpływowe kręgi gospodarcze Mołdawii i Ukrainy nie są zainteresowane takim rozwiązaniem, jakie zaproponował Juszczenko. Dla nich bowiem ta separatystyczna republika jest przysłowiową kurą znoszącą złote jajka. O sile i rozległych wpływach kapitału najlepiej świadczy dymisja rządu Ukrainy we wrześniu 2005 roku $^{36}$. Niestety, tylko w minimalny sposób udało się zrealizować plan Juszczenki. Ukraina zaś skompromitowała się i zniszczyła swój wizerunek

${ }^{33}$ Виктор Ющенко обсудит в Киеве свой мирный план с президентом Приднестровья, http:// www.newsru.com/world/14jul2005/smirnoff.html (dostęp 11 III 2012).

${ }^{34}$ Stanowi on uzupełnienie istniejącego wcześniej Planu Kozaka.

35 P. Świeżak, Mołdawia/Parlament zaakceptował plan Juszczenki, http://www.psz.pl/tekst-1485/ Moldawia-Parlament-zaakceptowal-plan-Juszczenki (dostęp 13 III 2012).

36 V. Dunaeva, op. cit., s. 80. 
zaufanego partnera przez wycofanie się z mającego wejść w życie 25 I 2006 r. międzynarodowego porozumienia podpisanego przez premierów Republiki Mołdawii i Ukrainy, dotyczącego przewożenia przez mołdawsko-ukraińską granicę towarów handlowych ${ }^{37}$. Ostatecznie po wielkich protestach porozumienie weszło w życie 3 III 2006. Przez władze Naddniestrza i FR zostało określone jako „blokada ekonomiczna”.

Rosja koniecznie chce zachować wojskową obecność w naddniestrzańskim regionie w celu zapobiegnięcia rozszerzeniu NATO na wschód. Nie ma jedności wśród tych, którzy mieli być sojusznikami w uregulowaniu konfliktu. Mołdawia cały czas domaga się przekształcenia obecnego „mechanizmu pokojowego" $\mathrm{w}$ rejonie Naddniestrza pod patronatem FR w misję cywilną z mandatu międzynarodowego. Stany Zjednoczone popierały to stanowisko, Niemcy zaś (które wprawdzie nie występują w imieniu UE) pomijały milczeniem kwestie obecności wojsk rosyjskich. W wyniku podpisanego 7 X 2005 r. memorandum miedzy Ukrainą, Mołdawią i Komisją Europejską została powołana misja graniczna EU BAM (cywilna o charakterze konsultacyjnym), która miała służyć pomocą w ochronie wspólnej granicy Mołdawsko-Ukraińskiej - właściwym zorganizowaniu posterunków kontroli granicznej i kontroli celnej ${ }^{38}$.

Ponieważ na kiszyniowskim szczycie poruszano również kwestie możliwości poszerzenia GUUAM o następne kraje, w Rosji pojawiły się plotki, iż do organizacji zamierza przyłączyć się Polska i Rumunia, co uczyniłoby z tej organizacji nową „Rzeczypospolitą od morza do morza” 39 . W mediach rosyjskich komentowano również potępienie przez państwa GUUAM Białorusi, głównego sojusznika Rosji, co interpretowano jako chęć przeprowadzenia w Mińsku „aksamitnej rewolucji” i poszerzenia GUUAM o ten $\mathrm{kraj}^{40}$. Strona rosyjska skomentowała kiszyniowski szczyt słowami Michaiła Margiełowa, przewodniczącego komisji spraw zagranicznych Rady Federacji Rosyjskiej, że jedynym celem GUUAM-u jest „eksport pomarańczowych rewolucji”"11. Administracja amerykańska w oficjalnych wystąpieniach wyrażała wolę wsparcia GUUAM w umacnianiu stabilności na obszarach byłego ZSRR ${ }^{42}$.

Również i te obrady GU(U)AM nie były zadowalające i nie stwarzały poczucia szansy na realizację zadeklarowanych dotąd założeń i celów. Dlatego też z inicjatywy W. Juszczenki w sierpniu 2005 r. prezydent Gruzji M. Saakaszwili i Ukrainy W. Juszczenko podpisali w Borżomi deklarację wzywającą do rozszerzenia procesów integracyjnych na państwa regionu bałtycko-czarnomorsko-kaspijskiego przez stworzenie Bloku Krajów Demokratycznego Wyboru (Ukraina, Gruzja, Estonia,

${ }^{37}$ M. Gołdysiak, Działalność Misji Unii Europejskiej o pomocy granicznej dla Ukrainy i Mołdawii (EU BAM) na tle naddniestrzańskiego konfliktu, „Dialogi Polityczne” 2007, nr 8, s. 73-77.

38 A. Ciupiński, Realizacja Wspólnej Polityki Bezpieczeństwa i Obrony UE na obszarze proradzieckim, [w:] A. Bryc, A. Legucka, A. Włodkowska-Bagan (red.), Bezpieczeństwo obszaru poradzieckiego, Warszawa 2011, s. 136-137.

39 V. Dunaeva, op. cit., s. 79.

40 H. Głębocki, Postscriptum: gier o Eurazję ciag dalszy, „Arcana”, 2005, nr 3, s. 144.

${ }^{41}$ V. Dunaeva, op. cit., s. 79.

42 H. Głębocki, op. cit., s. 144. 
Litwa, Łotwa, Macedonia, Mołdawia, Rumunia i Słowenia). Jako obserwatorów przewidziano UE, USA i $\mathrm{FR}^{43}$.

Kolejny szczyt, który odbył się w Kijowie 22-23 V 2006 r. był już bez udziału Uzbekistanu $^{44}$ - powrócono więc do pierwotnej nazwy GUAM. Przekształcono stowarzyszenie czterech państw w organizację międzynarodową GUAM - Organizację na Rzecz Demokracji i Rozwoju. Nadano jej statut, który miały ratyfikować parlamenty państw członkowskich. Celem organizacji jest sformalizowanie dotychczasowej współpracy, co ma usprawnić działania w zakresie polityki wewnętrznej i w kontekście wspólnych celów strategicznych w polityce zagranicznej. Organizacja będzie dążyć do zapewnienia bezpieczeństwa energetycznego poprzez realizację wspólnych inwestycji energetycznych, demokratyzacji, współpracy na rzecz rozwiązania konfliktów w regionie celem zapewnienia bezpieczeństwa na obszarze GUAM krajów członkowskich, wzmacniania demokracji, przestrzegania rządów prawa, zapewnienia ochrony praw człowieka $\mathrm{w}$ regionie, rozwoju ekonomicznego krajów członkowskich oraz integracji ze strukturami zachodnimi. Postanowiono, że zostanie wdrożona umowa o strefie wolnego handlu i powołana Rada Energetyczna. Struktura organizacji obejmuje Radę i Sekretariat. Rada jest głównym organem organizacji i prowadzi swoją pracę na szczeblu szefów państw (szczyt), ministrów spraw zagranicznych, krajowych koordynatorów i stałych przedstawicieli. Rada może tworzyć organy pomocnicze i robocze, stałe lub tymczasowe oraz organizować spotkania przedstawicieli odpowiednich ministerstw. Sekretariat organizacji z siedzibą w Kijowie działa pod kierownictwem sekretarza generalnego, realizuje zadania organizacyjno-techniczne. Decyzje podejmowane przez GUAM mają zapadać na zasadzie konsensusu. Organizacja ma podejmować dwustronne formy współpracy z ONZ, UE, USA, Polską, Czechami i Japonią. Na zorganizowanej w Kijowie konferencji prasowej starano się wypowiedziami nie antagonizować Rosji. Jedynie ze strony M. Saakaszwilego pojawiły się słowa krytyki pod adresem polityki zagranicznej prowadzonej przez Rosję. Prezydenci Mołdawii i Ukrainy starali się pokazać pozytywne aspekty współpracy z Rosją, prezydent Azerbejdżanu zaś stwierdził, że stosunki azersko-rosyjskie uważa za konstruktywne ${ }^{45}$.

Rok później spotkania na najwyższym szczeblu odbyły się w Baku (18-19 VI 2007). Szczyt w Baku był najliczniejszym spotkaniem, w którym uczestniczyli przedstawiciele 30 krajów (m.in. USA, Japonii, Chin) i organizacji międzynarodowych (OBWE, UE, NATO), w tym prezydenci Polski, Litwy i Rumunii. Ze względu na prorosyjski zwrot w polityce Mołdawii na szczycie nieobecny był $\mathrm{W}$. Woronin, a kraj reprezentował premier Vasile Tarle. Zresztą Mołdawia jako jedyna nie ratyfikowała

${ }^{43}$ E. Wyciszkiewicz, Perspektywy rozwoju organizacji GUUAM - polski punkt widzenia, „Polski Przegląd Dyplomatyczny", t. 5 (2006), nr 4 (26), s. 110; V. Dunaeva, op. cit., s. 79. Ostatecznie obserwatorami zostali: Azerbejdżan, Bułgaria, Czechy, Węgry, Polska i USA.

${ }^{44}$ Oficjalnie Uzbekistan wystąpił z organizacji 5 V 2005 roku.

45 A. Lemieszonek, op. cit.; Ł. Wróblewski, op. cit.; A. Górska, GUAM-nowa organizacja międzynarodowa, http://forum.gazeta.pl/forum/w,12217,42495412,42495412,GUAM_nowa_organizacja_miedzynarodowa.html (dostęp 23 II 2012). 
Deklaracji Kijowskiej i statutu GUAM. Mimo iż jednym z tematów obrad był problem nierozwiązanych konfliktów, to premier Mołdawii nie wspominał o konflikcie naddniestrzańskim, ten problem bowiem miał być omawiany na zaplanowanym na 22 VI spotkaniu w Moskwie W. Woronina z Władimirem Putinem. Głównym tematem rozmów w Baku były kwestie energetyczne, $w$ tym projekt przedłużenia ropociągu Odessa-Brody do Płocka i stworzenie wspólnego przedsiębiorstwa energetycznego ${ }^{46}$. Największą uwagę położono na wykorzystanie możliwości tranzytowych i rolę GUAM jako pomostu między Europą a Azją. Dużo miejsca poświęcono zagadnieniom międzynarodowego terroryzmu, separatyzmu i ekstremizmu oraz ponadnarodowej przestępczości zorganizowanej. Zwracano uwagę na przyjęcie wspólnej deklaracji GUAM-Polska. Odbyło się posiedzenie grupy roboczej GUAM-Polska, na którym omawiano kwestie współpracy energetycznej. Zapowiedziano mającą odbyć się miesiąc później konferencję naukowo-praktyczną poświęconą roli GUAM w regionie i świecie, wyrażając przekonanie, że podobne przedsięwzięcia mające na celu popularyzacje działalności organizacji będą odbywać się jak najczęściej ${ }^{47}$.

W ramach Forum Energetycznego, jakie odbyło się w Wilnie 10 X 2007 r. miały miejsce również rozmowy głów państw w ramach spotkania GUAM. Oprócz prezydentów Ukrainy, Gruzji i Azerbejdżanu oraz reprezentacji Mołdawii w szczycie wzięli udział prezydenci Polski, Litwy i Łotwy oraz amerykański wicesekretarz ds. energii. Podkreślono, że celem dalszej przyszłej współpracy jest silniejsza integracja regionu, rozwój współpracy ekonomicznej oraz prowadzenie dialogu między cywilizacjami ${ }^{48}$. Azerbejdżan, Gruzja, Ukraina, Litwa i Polska podpisały umowę o współpracy w sektorze energetycznym. Podpisano również umowy, w wyniku których Azerbejdżan, Gruzja i Litwa stały się udziałowcami spółki Sarmatia ${ }^{49}$.

Polska jest postrzegana przez kaukaskich członków GUAM jako idealny partner do integracji z UE, dlatego też dążą do zacieśniania relacji. Spotkanie koordynatorów RP-GUAM, które odbyło się 21 II 2008 r., poświęcone było wielostronnej współpracy w handlu, promocji, inwestycjach, energii, turystyce, transporcie i środowisku naturalnym. Zawarto porozumienie w sprawie zwiększenia obrotów handlowych między Polską a członkami GUAM. Duża część rozmów dotyczyła kwestii współpracy z UE, wprowadzania demokracji na terenie GUAM oraz prac nad dostosowaniem aktów prawnych w poszczególnych krajach członkowskich z europejskimi

\footnotetext{
${ }^{46}$ Za brak odpowiedniego wsparcia tego projektu winę ponosi w dużym stopniu UE - w tym i Polska.

47 W. Konończuk, Reakcje mediów rosyjskich na szczyt GUAM w Baku, http://www.osw.waw.pl/ pl/publikacje/tydzien-na-wschodzie/2007-06-20/reakcje-mediow-na-rosyjski-szczyt-GUAM-w-Baku (dostęp 19 I 2012); A. Lemieszonek, op. cit.; Szczyt GUAM w Azerbejdżanie, http://www.osw.waw.pl/ pl/publikacje/tydzien-na-wschodzie/2007-06-20/szczyt-guam-w-azerbejdzanie (dostęp 19 I 2012); Комюнике Бакийского саммита ГУАМ, http://guam-organization.org/node/344 (dostęp 28 III 2012); P. Andrusieczko, op. cit., s. 50.

48 A. Lemieszonek, op. cit.

49 Spółka Sarmatia została powołana trzy lata temu przez PERN Przyjaźń z Polski i UkrTransNafta z Ukrainy. Wówczas okazała się jednak za słaba na zbudowanie ropociągu Odessa-Brody-Gdańsk. Teraz do spółki przystąpiły azerski koncern SOCAR, gruziński GOGC i litewska firma Kłajpeda Nafta.
} 
normami i standardami. Organizacja zaprosiła wszystkich zainteresowanych do współdziałania w formacie GUAM $+{ }^{50}$.

Na konferencji w Baku (15-16 IV 2008), poświęconej uregulowaniu konfliktów na terytorium krajów członkowskich GUAM, ustalono, że jedynym statusem separatystycznych republik, na jaki mogą się zgodzić władze centralne, jest autonomia $\mathrm{z}$ szerokimi uprawnieniami, a konflikty powinny być rozwiązywane $\mathrm{w}$ oparciu o zasadę poszanowania integralności terytorialnej państw ${ }^{51}$. W konferencji wzięły udział delegacje ponad dziesięciu państw. Według obserwatorów Moskwę w roli mediatora w zażegnaniu zamrożonych konfliktów na terenach Gruzji, Azerbejdżanu i Mołdawii mogłaby zastąpić Ukraina ${ }^{52}$.

Kolejny ze szczytów GUAM odbył się w Batumi (1 VII 2008) pod hasłem GUAM - Integrowanie Europy Wschodniej. Gośćmi szczytu byli przedstawiciele prawie 20 państw, w tym prezydenci Polski i Litwy. Również i ten szczyt wykazał, że Mołdawia nie jest zainteresowana współpracą w ramach tej organizacji, ponieważ kraj reprezentowany był tylko przez ministra spraw wewnętrznych i wiceministra spraw zagranicznych. Podpisano deklarację potwierdzającą m.in. wolę współpracy regionalnej, współdziałanie w walce ze współczesnymi zagrożeniami, gotowość do dalszego rozwijania systemu bezpieczeństwa energetycznego i wspierania wysiłków na rzecz liberalizacji i dywersyfikacji europejskiego rynku nośników energii, jak również oświadczenie dotyczące rozwoju korytarza transportowego GUAM. Omawiano zagadnienie integralności terytorialnej państw członkowskich. Podpisano deklarację o stałym rozwijaniu integracji i bezpieczeństwa w regionie GUAM, który stanowi integralną część obszaru ogólnoeuropejskiego i euroazjatyckiego. Wspomniano o nawiązaniu współpracy pomiędzy GUAM a państwami Grupy Wyszehradzkiej oraz państwami bałtyckimi. Odbyto kilka sesji dwustronnych, m.in. Polska-GUAM. Jako policzek wymierzony Rosji można uważać wspólne oświadczenie o wsparciu Ukrainy w przekazaniu międzynarodowej społeczności prawdy o Wielkim Głodzie, ocenionym jako przestępstwo przeciw ludzkości. Organizacja potwierdziła obecność na obchodach rocznicy 75-lecia Wielkiego Głodu na Ukrainie. Komentatorzy podsumowali szczyt stwierdzeniem, że przyjęte dokumenty będą, wzorem poprzednich wspólnych zobowiązań, miały jedynie wartość archiwalną ${ }^{53}$.

${ }^{50}$ N. Domaniewska, Polska/Polska wspiera państwa GUAM,http://www.psz.pl/tekst-9109/ Polska-Polska-wspiera-panstwa-GUAM (dostęp 19 I 2012); Варшавское заявление СМИД ГУАМ, http://guam-organization.org/node/1215 (dostęp 28 III 2012).

${ }^{51}$ Prezydent W. Juszczenko chciał, aby kwestia ta stała się swego rodzaju wizytówką działalności GUAM.

52 A. Kowalczuk, Azerbejdżan/Konferencja GUAM na rzecz uregulowania konfliktów, http://www. psz.pl/index.php?option=com_content\&task=view\&id=10442 (dostęp 19 I 2012).

${ }^{53}$ Szczyt GUA(M) w Gruzji, http://www.osw.waw.pl/pl/publikacje/tydzien-na-wschodzie/2008-07-09/ szczyt-guam-w-gruzji (dostęp 19 I 2012); A. Lemieszonek, op. cit.; M. Jastrzębska, Kaczyński: „Trzeba walczyć do końca", http://www.psz.pl/tekst-11775/Kaczynski-Trzeba-walczyc-do-konca (dostęp 19 I 2012); Коммюнике Батумского саммита Гуам, http://guam-organization.org/node/373 (dostęp 28 III 2012); Меморандум о взаимопонимании между Организацей, http://guam-organization.org./ node/378 (dostęp 28 III 2012). 
Próby ożywienia GUAM podjęli w sierpniu 2010 r. M. Saakaszwili i p.o. prezydenta Mołdawii Michaia Ghimpu. Na spotkaniu przywódców omawiano również projekt zaproszenia do GUAM Białorusi, będącej w konflikcie z Rosją. Według rosyjskich mediów jest to próba zastąpienia Ukrainy, „która pod kierownictwem Wiktora Janukowycza zbliżyła się do Moskwy i nie przejawia chęci okazywania wsparcia politycznego" GUAM ${ }^{54}$. Gruziński MSZ informował, że do końca roku najprawdopodobniej odbędzie się kolejny szczyt GUAM ${ }^{55}$. Niestety, postępująca rozbieżność celów państw członkowskich nie pozwala na zwołanie do tej pory kolejnego szczytu GUAM.

We wrześniu 2008 r. odbyło się w Nowym Jorku posiedzenie grupy roboczej GUAM (ministrowie spraw zagranicznych państw członkowskich) - USA. Wyrażono przekonanie, że międzynarodowe organizacje powinny zintensyfikować swoje działania w celu uregulowania przewlekłych konfliktów w regionie GUAM z poszanowaniem suwerenności i nienaruszalności granic państw członków organizacji oraz prawa międzynarodowego. Rozmawiano również na temat walki z terroryzmem, zorganizowaną przestępczością i handlem narkotykami oraz pomocy służbom granicznym państw członkowskich w zabezpieczeniu bezpieczeństwa Transportowego Korytarza GUAM. Organizacja z uznaniem wyraziła się o pomocy technologicznej uzyskanej od USA ${ }^{56}$.

Spotkanie w ramach GUAM przy okazji szczytu OBWE, który odbył się 1-2 XII 2010 w Astanie, miało pokazać, że mimo znacznych różnic między sferą deklaracji a praktyką, GUAM stara się realizować przynajmniej część z przyjętych założeń. Tylko w listopadzie i grudniu 2010 r. odbyło się dziesięć spotkań przedstawicieli GUAM, nie licząc spotkań samego sekretarza generalnego GUAM ${ }^{57}$. Sekretarz generalny organizacji stara się prowadzić ożywioną działalność. W maju 2012 r. gościł w Wiedniu, gdzie miał spotkanie ze słuchaczami Akademii Dyplomatycznej i wygłosił wykład na temat działalności GUAM i programów przez nie realizowanych oraz spotkał się z generalnym sekretarzem OBWE ${ }^{58}$. Miesiąc później w Kijowie spotkał się z dyrektorem Południowo-Wschodniego Europejskiego Centrum Ochrony Porządku Publicznego ${ }^{59}$, z którym omawiał priorytety w zadaniach obu organizacji $\mathrm{w}$ sferze walki z przestępczością i terroryzmem ${ }^{60}$.

54 Podczas gruzińsko-rosyjskiej wojny w 2008 r. Wiktor Janukowycz opowiedział się za niepodległością Osetii Południowej i Abchazji.

55 Saakaszwili i Ghimpu chca ożywić GUAM, http://www.wprost.pl/ar/206046/ Saakaszwili-i-Ghimpu-chca-ozywic-GUAM (dostęp 16 IV 2012).

56 Wykorzystanej głównie do wyposażenia kijowskiego sekretariatu, Совместное заявлене ГУАМ-США, http://guam-organization.org/node/512 (dostęp 28 III 2012).

57 P. Andrusieczko, op. cit., s. 51-52.

58 Рабочий визит Генеральново секретаря ГУАМ г-на В. Чечелашвили в Вену, http://guam-organization.org/node/1329 (dostęp 26 VI 2012).

59 SELEC - Southeast European Law Enforcement Center.

${ }^{60}$ Встреча Генерального секрегаря ГУАМ г-на В.Чечелашвили с Директором SELEC, http:// guam-organization.org/node/1335 (dostęp 1 VII 2012). 
Niestety, były to ostatnie z ważniejszych inicjatyw GUAM. W późniejszym okresie prace $w$ ramach organizacji polegały na organizowanych co jakiś czas spotkaniach grup roboczych czy narodowych koordynatorów. Organizacja skupia się na drobniejszych, bieżących sprawach. Sporą część aktywności stanowią także konferencje i wideo konferencje oraz działalność informacyjna - poprzez stronę internetową czy wydawane publikacje ${ }^{61}$. Wszystkie te formy działalności znalazły się w przedstawionym przez Gruzję w 2008 r. programie jej przewodnictwa w organizacji, która postulowała również utworzenie Banku Inwestycyjnego GUAM ${ }^{62}$. Azerbejdżan inicjuje posiedzenia grupy roboczej GUAM zajmującej się sprawami energetyki. Organizacja rozpoczęła współpracę na tym polu z Japonią, która organizuje seminaria poświęcone bezpieczeństwu energetycznemu dla ekspertów z państw członkowskich (m.in. w dniach 15-23 I 2012 r.). Zapowiedziano zorganizowanie biznes-forum $\mathrm{w}$ celu przedstawienia nowych projektów w sferze energetyki dla wiodących firm z krajów GUAM i spoza ${ }^{63}$. Japonia jest również zainteresowana rozwojem turystyki na terenie regionu i wspomaga prace turystycznej grupy roboczej GUAM ${ }^{64}$. Azerbejdżan, który w 2012 r. przejął przewodnictwo w GUAM, jako priorytety podał: współpracę w zakresie ujednolicenia prawa państw członkowskich, rozwój międzynarodowej współpracy gospodarczej, wprowadzenie schematu współpracy między parlamentami państw członkowskich ${ }^{65}$. Do tej pory odbyło się pięć posiedzeń Zgromadzenia Parlamentarnego GUAM. Sekretarz generalny organizacji przykłada szczególne znaczenie do współpracy parlamentarnej, która przyczynić się ma do dalszego promowania formatu GUAM i terminowego zakończenia procedur ratyfikacyjnych ${ }^{66}$. Ostatnie posiedzenie Rady Narodowych Koordynatorów GUAM, w którym uczestniczyli: minister spraw zagranicznych Azerbejdżanu oraz wiceministrowie spraw zagranicznych Gruzji, Mołdawii i Ukrainy, odbyło się w Baku 9-10 IV 2012 roku. Podniesiono kwestie skutecznej realizacji projektów w obszarze: ekonomii, handlu, transportu, energetyki, turystyki i walki ze zorganizowaną przestępczością. Zostały podjęte decyzje o realizacji bieżących i przygotowaniu nowych projektów w programie współpracy GUAM i GUAM $+{ }^{67}$. Aktywna w ostatnim czasie jest też grupa robocza zajmująca się nadzwyczajnymi sytuacjami. Zajmowała się m.in. opracowaniem przedsięwzięcia skutecznych środków w radzeniu sobie

${ }^{61}$ Szczegółowe informacje o działaniach na stronie organizacji, http://guam-organization.org/.

${ }^{62}$ Програма председательства Грузии в Организации, http://guam-organization.org/node/377 (dostęp 28 III 2012).

${ }^{63}$ 6-е заседание Рабочей группы по енергетике, http://www.guam-organization.org/node/1295 (dostęp 28 III 2012).

${ }^{64}$ Видеоконференция представителей туристических администраций, http://www.guam-organization.org/node/1301 (dostęp 4 IV 2012).

${ }^{65}$ Azerbejdżan przejął przewodnictwo w GUAM, http://www.portal.arcana.pl/Azerbejdzan-przej al-przewodnictwo-w-guam,2078.html (dostęp 19 VI 2012).

66 Участие Генерального секретаря в 5-м заседании Парламентской Ансамблей ГУАМ, http:// www.guam-organization.org/node/1408/ (dostęp 18 II 2013).

67 24-е Заседание Совета Национальных кординаторов ГУАМ, http://www.guam-organization. org/node/1305 (dostęp 16 IV 2012). 
z masowymi skupiskami ludzi i zagrożeniami, jakie mogą one nieść dla bezpieczeństwa. Dotyczyło to m.in. konkursu Eurowizji w Azerbejdżanie i Finału Mistrzostw Europy w Kijowie ${ }^{68}$. Coraz większego znaczenia nabierają prace grupy roboczej zajmującej się walką z terroryzmem, zorganizowaną przestępczością i handlem narkotykami. W tym ostatnim przypadku wzrasta zagrożenie w związku z sytuacją w sąsiednim Afganistanie ${ }^{69}$. Ostatnie posiedzenie ministrów spraw zagranicznych państw GUAM, odbyło się 7 XII 2012 r. w Dublinie w ramach XIX posiedzenia Rady Ministrów Spraw Zagranicznych krajów członkowskich OBWE. Omówiono projekt uchwały Dlugotrwałe konflikty na obszarze GUAM i ich konsekwencje dla międzynarodowego pokoju, bezpieczeństwa i rozwoju, który zaplanowano przedstawić do dyskusji w ONZ. Rozpatrywano także kwestie zwołania w 2013 r. następnego szczytu GUAM w Baku ${ }^{70}$.

\section{Współpraca w ramach GU(U)AM}

Należy pamiętać, że na uczestnictwo poszczególnych państw w strukturze GU(U) AM wpływ miało również podążanie przez nie różnymi drogami rozwoju politycznego i ustrojowego. Odmienny jest więc poziom zaangażowania członków we współpracę. Największe zainteresowanie i aktywność przejawiają Ukraina i Gruzja. Wiktor Juszczenko definitywnie zerwał z polityką wielowektorowości i za najważniejsze cele w polityce zagranicznej uznał uzyskanie członkostwa w NATO i UE. Dla Ukrainy za prezydentury Juszczenki GUAM był przedsionkiem do NATO i stwarzał możliwość na ściślejsze relacje z UE (chociażby przez umocnienie współpracy w sferach energetyki, transportu i polityki bezpieczeństwa), był też elementem wzmacniania pozycji lidera regionalnego ${ }^{71}$. Azerbejdżan zaś stara się zachować równowagę pomiędzy Rosją a aktywnością w GUAM i stosunkami z USA ze względów gospodarczych i politycznych. Z powodu silnych wpływów Rosji i powiązań gospodarczych również Mołdawia nie angażowała się zbyt mocno we współpracę w ramach GUAM ${ }^{72}$. Mało aktywny był również Uzbekistan, który zawiesił swoje członkostwo w GUUAM w 2002 roku. W czerwcu 2004 r. doszło do podpisania uzbecko-rosyjskiej umowy o strategicznym partnerstwie. Powodem zmiany orientacji

68 7-е заседание Рабочей группи по чрезвычайным сытуациям, http://www.guam-organization. org/node/1306 (dostęp 16 IV 2012).

69 15-е заседание Рабочей группы по борбе с терроризмом, органзованной преступностью распостранением наркотиков (РГБТОП)29-30 ХI 2012, http://www.guam-organization.org/ node/1393 (dostęp 6 II 2013).

${ }^{70}$ Następny szczyt GUAM odbędzie się w Azerbejdżanie, http://www.studium.uw.edu.pl/?post/15096 (dostęp 5 II 2013).

${ }^{71} \mathrm{Na}$ temat programu politycznego W. Juszczenki zob. M. Figura, Europejskie aspiracje Ukrainy w pierwszych miesiacach po zwycięstwie „Pomarańczowej rewolucji”, [w:] „Pomarańczowa rewolucja”szansa dla ukraińskiej transformacji politycznej, red. A. Furier, Szczecin 2006, s. 73-82; K. Fedorowicz, „Pomarańczowa rewolucja” na Ukrainie - czas realizacji wyborczych deklaracji, [w: ] „Pomarańczowa rewolucja”- szansa..., s. 134-140.

72 Przed szczytem GUAM w Batumi Rosja zniosła bardzo uciążliwy dla Mołdawii zakaz importu tamtejszych win - w efekcie na szczycie nie pojawił się prezydent tego kraju. 
Uzbekistanu miało być rozczarowanie współpracą z USA oraz krytyczne stanowisko Waszyngtonu wobec sytuacji wewnętrznej $\mathrm{w}$ tym $\mathrm{kraju}^{73}$. Uzbekistan zawiadomił o wystąpieniu z GUUAM 5 V 2005 r., podając jako oficjalną wersję zmianę przez organizację pierwotnie ogłoszonych celów i zadań poprzez położenie akcentu na ideologiczny i wojenno-polityczny rodzaj współpracy w ramach GUUAM. Według Taszkentu organizacja koncentruje się na rozwiązywaniu zamrożonych konfliktów, formowaniu wspólnych bloków zbrojnych i weryfikowaniu istniejących systemów bezpieczeństwa, a w takich działaniach Uzbekistan $\mathrm{z}$ racji swojego położenia geograficznego nie może uczestniczyć. Jako powód podjęcia tego kroku podawano obawę Taszkentu przed rozprzestrzenieniem się haseł „zwycięskich demokracji” (Ukraina, Gruzja). Przyczyna rezygnacji wiązana była również z obietnicą Rosji wsparcia gospodarki uzbeckiej. Na szczyt do Kiszyniowa prezydent Uzbekistanu już nie przyjechał, bo jak mówiono, bał się tematów, które miały być poruszane na szczycie - kwestii praw człowieka i mechanizmów demokratycznych ${ }^{74}$. Obawy Islama Karimowa miały swoje uzasadnienie. Nie chciał u siebie podobnego scenariuszu, jaki nastąpił w Kirgizji, która chciała lawirować między Rosją i USA, a dla której skończyło się to krwawą „kasztanową rewolucją”75. Jednak po wydarzeniach w Gruzji (2008 r.) i wobec rosnącej roli Rosji i Chin oraz słabnącej pozycji Zachodu w regionie Uzbekistan zdecydował się na nowo zacieśniać współpracę w regionie, czego efektem była wizyta prezydenta I. Karimowa w Baku (11 IX 2008) ${ }^{76}$.

Trzon porozumienia GU(U)AM tworzyły do 2005 r. Gruzja i Azerbejdżan (Ukraina sporadycznie się aktywizowała, wychodząc na lidera dopiero po wyborze W. Juszczenki na prezydenta), w największym stopniu zainteresowane rozwijaniem wzajemnych stosunków. Ponieważ wszystkie państwa GUUAM uzależnione są od dostaw surowców energetycznych z Rosji, natomiast Azerbejdżan jest zależny $\mathrm{w}$ kwestii transportu ropy i gazu od rosyjskiej infrastruktury transportowej, to dlatego najważniejsze było dla nich wytyczenie i budowa sieci rurociągów mających transportować gaz i ropę z Kaukazu, Azji Środkowej i Morza Kaspijskiego do Europy oraz usprawnienie szlaków komunikacyjnych - czemu służy projekt TRACECA, w który zaangażowana jest UE oraz USA. Podczas szczytów GU(U)AM niezwykle ważne były rozmowy na temat budowy ropociągów Baku-Tbilisi-Ceyhan, Baku-Tilisi-Supsa, przewidując transport morski do terminalu w Odessie i dalej przez Gdańsk do Europy Zachodniej. Realizacja takich wielkich projektów jest uzależniona od poparcia najważniejszych geopolitycznych graczy, jak USA i UE. Celem tych inwestycji jest pozbycie się pośrednictwa Rosji i uniezależnienie ekonomiczne stron porozumienia. Liczono także, iż na rynku energii inicjatywa GUUAM mogłaby

73 A. Lemieszonek, op. cit.

${ }^{74}$ M. Stokłosa, Uzbekistan/ Z GUUAM już tylko GUAM, http://www.psz.pl/tekst-1326/ Uzbekistan-Z-GUUAM-juz-tylko-GUAM (dostęp 19 I 2012); P. Andrusieczko, op. cit., s. 48.

${ }^{75}$ H. Głębocki, op. cit., s. 144.

${ }^{76}$ Kontakty między obu krajami nawet w ramach współpracy w GUUAM były bardzo ograniczone, Prezydent Karimow w Azerbejdżanie, http://www.osw.waw.pl/pl/publikacje/tydzien-na-wschodzie/2008-09-18/prezydent-karimow-w-azerbejdzanie (dostęp 19 I 2012). 
skutecznie konkurować ze zdominowaną przez Rosję Euroazjatycką Wspólnotą Gospodarczą. Co zresztą zostało dane wyraźnie do zrozumienia na szczycie państw GUUAM w Jałcie w 2001 roku. Organizacja była zainteresowana zacieśnianiem współpracy z Turcją, Bułgarią, Rumunią, a w budowie własnego dobrobytu ekonomicznego szuka sojuszników na Zachodzie ${ }^{77}$. Inwestycje związane $z$ kwestiami energetycznymi okazały się najbardziej realnymi możliwościami regionalnej współpracy między członkami GUUAM. Ukończenie rurociągu Odessa-Brody, sfinansowanego przez stronę ukraińską, możemy zaliczyć do kolejnego sukcesu GUAM na polu współpracy energetycznej.

Najbardziej zmienne podejście do organizacji miała Mołdawia, która niejednokrotnie publicznie wypowiadała się bardzo sceptyczne na temat GU(U)AM.

Barierą hamującą rozwój wspólpracy w ramach GU(U)AM jest niski stopień powiązań gospodarek państw członkowskich - przede wszystkim w kwestii wzajemnych inwestycji, ale również i wymiany handlowej. Rozwój wymiany handlowej w ramach GU(U)AM hamuje brak priorytetowego traktowania członków tej organizacji przez uczestników porozumienia. Według badań przeprowadzonych w $2001 \mathrm{r}$. na Ukrainie wśród ekspertów i społeczeństwa, państwa GUUAM zajmowały szóste bądź ósme miejsce w priorytetach współpracy zagranicznej Ukrainy (po UE, USA, ZBiR, Radzie Europy, NATO, WNP oraz ONZ) ${ }^{78}$. Problemem było porozumienie się członków w sprawie wspólnych projektów - w efekcie nie można było nawet wydać większości środków (rzędu 40-50 mln dolarów rocznie) przekazywanych przez amerykański Kongres ${ }^{79}$.

Współpraca gospodarcza wewnątrz GU(U)AM specjalnych zysków nie przynosiła. Wszystkie kraje członkowskie borykają się z różnymi kłopotami gospodarczymi, a ich głównymi partnerami handlowymi pozostają UE i FR. Państwa GU(U)AM liczyły na wsparcie z Zachodu. Umowa o wolnym handlu niewiele mogła zmienić w gospodarce niektórych krajów, np. Gruzji i Mołdawii, które już wcześniej zarzuciły swoimi produktami rynek ukraiński. Ukraina gospodarczo większe korzyści widzi we współpracy z FR. Dlatego też zdecydowała się na przystąpienie do Wspólnej Przestrzeni Gospodarczej ${ }^{80}$. Podpisanie na kijowskim szczycie w 2006 r. porozumienia o ustanowieniu strefy wolnego handlu zostało przez rosyjską „Niezawisimą Gazetę” skomentowane jako zrezygnowanie przez Ukrainę z udziału w rosyjskim projekcie Wspólnej Przestrzeni Gospodarczej ${ }^{81}$. Mimo iż potencjał ekonomiczny państw GUAM nie jest duży, to w ciągu ostatnich kilku lat wymiana handlowa w ramach GUAM wzrosła trzykrotnie (mimo wojny i kryzysu ekonomicznego) i osiągnęła poziom 4,5 mld USD. Wzrasta również znaczenie tranzytowego korytarza GUAM.

77 J. Siekierzyński, op. cit., s. 64-65.

78 S. Jasiniecki, GU(U)AM-Szansa na dywersyfikację dostaw zasobów energetycznych do Europy, „Dialogi Polityczne”, nr 7, marzec 2007, http://www.dialogi.umk.pl/guuam-szansa-energetyka.html (dostęp 5 II 2012).

79 E. Wyciszkiewicz, Perspektywy rozwoju organizacji GUUAM - polski punkt..., s. 104.

${ }^{80}$ Struktura ta powstała w maju 2004 i skupia: Rosję, Białoruś, Ukrainę oraz Kazachstan.

81 P. Andrusieczko, op. cit., s. 49. 
W 2009 r. azerbejdżańska ropa pokryła 25\% zapotrzebowania Ukrainy na produkty naftowe $^{82}$. UE zdecydowanie woli angażować się w budowanie rurociągów biegnących z regionu Morza Kaspijskiego, niż w kupowanie towarów wytwarzanych na Zakaukaziu, jak chociażby gruzińskiego wina, którego największym importerem była Rosja ${ }^{83}$. Po nałożeniu przez Moskwę embarga na ukraińskie mięso i gruzińskie wino, jedynie GUAM i Litwa wykazały solidarność gospodarczą i zadeklarowały zainteresowanie tymi produktami ${ }^{84}$. Współpraca gospodarcza państw GUAM skoncentrowana na długoterminowych projektach infrastrukturalnych jest uzależniona wyłącznie od przyciągnięcia inwestorów z USA i UE.KWESTIE BEZPIECZEŃSTWA

Kolejną ważną płaszczyzną współpracy GU(U)AM miała być kooperacja w sferze politycznej i wojskowej. Od momentu powstania organizacji kraje GU(U)AM składały deklaracje w ramach działania w takich organizacjach, jak ONZ czy Rada Europy. Od początku nie było jedności, jeśli chodzi o kwestie współpracy militarnej. Najgorętszymi orędownikami poszerzenia takiej współpracy były Ukraina i Gruzja. Nie udało się przekształcić GUUAM w organizację o charakterze militarnym, czego próbowano dokonać na szczycie w Jałcie w 2001 r., a co skutecznie zablokowały Uzbekistan i Azerbejdżan, wymuszając rezygnację w karcie jałtańskiej zapisów o pogłębianiu współpracy militarnej i działalności wspólnych sił pokojowych ${ }^{85}$. Rozwój kooperacji wojskowej między krajami GU(U)AM hamuje obecność baz rosyjskich na terytorium Gruzji, Azerbejdżanu i Mołdawii. Zapewne też był to jeden z powodów, dla których NATO odrzuciło inicjatywę współpracy zaproponowaną przez GU(U)AM. Sojusz orzekł, że preferuje współpracę w ramach Partnerstwa dla pokoju z każdym z krajów GUAM z osobna (co sprowadza się do handlu i modernizacji uzbrojenia oraz szkolenia i uczestniczenia w ćwiczeniach organizowanych przez NATO ${ }^{86}$. Trudno jednak współpracować w sferze politycznej i wojskowej, jeżeli większość członków GUAM prowadzi nadal politykę balansowania między Rosją a Zachodem. Jak w takiej sytuacji można odczytywać np. słowa wypowiedziane w czasie wizyty W. Putina w Azerbejdżanie (21-22 II 2006) przez prezydenta Ilhama Alijewa: „stosunki Rosji i Azerbejdżanu mają charakter strategicznego partnerstwa"87. Strategia Bezpieczeństwa Gruzji podkreśla aspiracje tego kraju do osiągnięcia pełnej integracji z NATO oraz wysiłki w celu podniesienia poziomu bezpieczeństwa w regionie Morza Czarnego jako Elementu Euroatlantyckiego systemu bezpieczeństwa ${ }^{88}$. NATO opracowało dla Gruzji Indywidualny partnerski

\footnotetext{
${ }^{82}$ Ibidem, s. 51.

${ }^{83}$ W 2006 r. Rosja wprowadziła embargo na gruzińskie produkty spożywcze i w praktyce wprowadziła blokadę gospodarczą.

${ }^{84}$ D. Kałan, GUAM - fiasko dobrych intencji, http://www.psz.pl/tekst-33260/Dariusz-KalanGuam-fiasko-dobrych-intencji (dostęp 19 I 2012).

${ }^{85}$ S. Jasiniecki, op. cit.; P. Andrusieczko, op. cit., s. 45.

${ }^{86}$ Ibidem.

87 Cyt. za J. Brodowski, op. cit., s. 98.

88 A. Igharkava, Rola NATO w gruzińskiej strategii bezpieczeństwa narodowego, [w:] W. Baluk (red.), Polityka zagraniczna i bezpieczeństwa krajów Wspólnoty Niepodległych Państw, Wrocław 2008, s. 201.
} 
plan działania. Po przyjęciu programu „Wyszkolić i wyposażyć”, w ramach którego rząd USA podjął się finansowania i rozwoju armii gruzińskiej, kraj ten stał się głównym partnerem Gruzji w sprawach bezpieczeństwa ${ }^{89}$. Z punktu widzenia gospodarki kandydowanie do NATO czyni Gruzję krajem bardziej atrakcyjnym i bezpiecznym dla zagranicznych inwestorów ${ }^{90}$. Zaufanie do Paktu nadwyrężyła wojna gruzińsko-rosyjska z 2008 r. i dopiero od roku 2011 kontakty Gruzji z NATO zaczęły powracać do okresu sprzed „wojny pięciodniowej" ${ }^{11}$. W Azerbejdżanie nie było i nie ma jedności w poglądach na temat związania się z NATO. Politycy azerscy kilkakrotnie deklarowali zamiar wstąpienia do sojuszu, ale nie potwierdził tego prezydent. Azerbejdżan rozwija współpracę z NATO, ale nie wszyscy politycy to popierają $^{92}$. W ostatnim czasie w związku z możliwością potencjalnego ataku USA na Iran nastąpiło wzmocnienie zainteresowania NATO Azerbejdżanem. Ewentualna wojna Zachodu z Iranem oraz przyjęcie Azerbejdżanu do NATO otwierają przed Baku perspektywę budowy „Wielkiego Azerbejdżanu” kosztem Iranu ${ }^{93}$. Według rosyjskiego szefa Centrum Prognozowania Wojskowego płka Anatolija Tsyganoka „możliwe jest w przypadku wojny z Iranem wciągnięcie postsowieckich republik na Kaukazie Południowym w konflikt zbrojny"94. Pozostaje pytanie, gdzie miałaby miejsce ewentualna interwencja FR (w Gruzji, Azerbejdżanie)?

Państwa członkowskie GUUAM po wydarzeniach z 11 IX 2001 r. przystąpiły do koalicji antyterrorystycznej. Głównym beneficjentem środków pieniężnych przeznaczonych na walkę z terroryzmem stał się Uzbekistan. Zadecydowało o tym jego położenie w samym sercu Azji Środkowej (co czyni go narażonym z każdej strony na agresję) oraz posiadanie przez niego, jako jedynego kraju w tym regionie, sprawnie funkcjonującej armii. Na tą decyzję swój wpływ miał również fakt, iż Uzbekistan, bez pytania Moskwy o zgodę, udostępnił USA swoje bazy wojskowe ${ }^{95}$. Niestety, większa część tych środków została zdefraudowana bądź przeznaczona na inne cele. Do 2003 r. Uzbekistan współpracował z USA (szkolono oficerów uzbeckich), które

${ }^{89}$ Gruzja popiera politykę zagraniczną USA i wysłała do Iraku jeden z największych kontyngentów (drugi z nienatowskich) - 850 żołnierzy - nie zapowiadając daty zakończenia misji. J. Stańczyk, Gruzja, [w:] J. M. Fiszer (red.), Systemy polityczne oraz polityka wewnętrzna i zagraniczna w państwach postkomunistycznych Europy i Azji w latach 2004-2005, Warszawa 2005, s. 147.

90 A. Igharkava, op. cit., s. 207.

91 P. A. Maciążek, Gruzja w NATO? Rasmussen potwierdza, http://politykawschodnia.pl/index. php/2012/04/12/maciazek-gruzja-w-nato-rasmussen-potwierdza.html (dostęp 17 IV 2012).

92 A. Orzelska, Azerbejdżan, [w:] J. M. Fiszer (red.), op. cit., s. 141.

93 Mniejszość azerska w Iranie stanowi 24\% całej populacji. P. Woźniak, Idea „Wielkiego Azerbejdżanu”, http://politykawschodnia.pl/index.php/2012/02/15/wozniak-idea-wielkiego-azerbejdzanu.html (dostęp 19 IV 2012).

${ }^{94}$ Cyt. za P. A. Maciążek, Kreml potrzebuje wojny na Kaukazie, http://politykawschodnia.pl/index. php/2012/01/20/maciazek-kreml-potrzebuje-wojny-na-Kaukazie (dostęp 21 III 2012). Pułkownik Tsyganok jest także autorem wydanej w 2012 r. książki o wojnie sierpniowej 2008 r., zob. А. Цыганок, Война на Кавказе 2008: Русский взгляд.

95 Szerzej: M. A. Piotrowski, Azja Środkowa po 11 września, „Sprawy Międzynarodowe”, 2002, nr 1, s. 155-157; Z. Lewicki, Ewolucja polityki USA wobec Azji po 11 września, „Sprawy Międzynarodowe” 2002, nr 1, s. 63. 
zrezygnowało $\mathrm{z}$ interweniowania $\mathrm{w}$ sprawie łamania praw człowieka przez reżim Islama Karimowa ${ }^{96}$. Dyplomacja amerykańska zaktywizowała również Turcję do zacieśniania kontaktów w tym regionie - m.in. z Azerbejdżanem i Gruzją ${ }^{97}$.

Mimo iż Ukraina należy do członków GU(U)AM, którzy najgłośniej zabiegają o rozwinięcie współpracy militarnej przy wsparciu Zachodu, to właśnie pod względem bezpieczeństwa nie uwolniła się od powiązań z Rosją. Kiedy w 2002 r. reorganizowano układ taszkiencki i powstawała Organizacja Układu O Bezpieczeństwie Zbiorowym (OUOBZ), Ukraina oficjalnie zadeklarowała chęć przystąpienia w przyszłości do struktur NATO ${ }^{98}$. Ukraina jest jednak obserwatorem w czasie najważniejszych posiedzeń OUOBZ, posiada bowiem pozostawione po ZSRR elementy systemu ostrzegawczego przed atakiem powietrznym lub rakietowym, jest uczestnikiem specjalnej umowy $\mathrm{w}$ ramach WNP, określającej ich wykorzystanie. Ma także podpisaną z Moskwą umowę o informacji aeronawigacyjnej ${ }^{99}$. W sferze bezpieczeństwa widoczne jest, że Ukrainę cechuje brak przemyślanej i konsekwentnej strategii względem Federacji Rosyjskiej. Oba państwa współpracują ze sobą w wojskowo-technicznej dziedzinie ${ }^{100}$. W ramach WNP na poziomie subregionalnym Ukraina i Rosja współpracują ze sobą poprzez Antyterrorystyczne Centrum WNP, które rozpoczęło swą działalność w czerwcu 2000 r. oraz poprzez Biuro Koordynacji Walki z Przestępczością Zorganizowaną ${ }^{101}$. Funkcjonowanie ogólnego bezpieczeństwa zbiorowego WNP stało się czynnikiem przeszkadzającym państwom dążącym do integracji z NATO. Ukraina chce występować jako ogniwo potencjalnie łączące systemy bezpieczeństwa Zachodu i Wschodu. Po „pomarańczowej rewolucji” W. Juszczenko zadeklarował w lutym 2005 r. członkostwo w NATO jako cel ostateczny współpracy Ukrainy i Sojuszu ${ }^{102}$.

Inicjatywą GUUAM była chęć stworzenia wspólnej jednostki wojskowej dla obrony rurociągu Baku-Supsa. Wprawdzie na wiosnę 2001 r. odbyły się w Gruzji wspólne ćwiczenia wojskowych ukraińskich, gruzińskich i azerskich, to jednak nie udało się stworzyć wspólnej jednostki wojskowej ${ }^{103}$.

Na szczycie GU(U)AM w Kiszyniowie Gruzja i Ukraina opowiadały się za stworzeniem w regionach konfliktowych własnych sił pokojowych pod egidą ONZ lub OBWE ${ }^{104}$. Byłoby to dla tych państw najlepsze rozwiązanie. W sierpniu 2006 r. na spotkaniu reprezentantów ministerstw obrony narodowej oraz sztabów generalnych

${ }^{96}$ H. Głębocki, Gry w islam. Radykalizm islamski w polityce Rosji na Kaukazie, [w:] idem, Kresy Imperium. Szkice i materiały do dziejów polityki Rosji wobec jej peryferii (XVIII-XXI wiek), Kraków 2006, s. 538-540; J. Siekierzyński, op. cit., s. 66.

97 J. Siekierzyński, op. cit., s. 66; A. Myśliwy, op. cit., s. 136.

98 T. Kapuśniak, Y. Tymkiv, Polityka zagraniczna i bezpieczeństwa Ukrainy w czasie prezydentury Wiktora Juszczenki, Prace Instytutu Europy Środkowo-Wschodniej, Lublin-Lwów 2009, s. 18-19.

99 Ibidem, s. 20.

100 Ibidem, s. 21.

101 Ibidem, s. 21-22.

102 Ibidem, s. 25.

103 J. Darski, GUUAM, http://darski.niezalezna.pl/node/1719 (dostęp 19 I 2012).

104 H. Głębocki, Postscriptum: gier o Eurazję..., s. 144. 
państw należących do GUAM, które odbyło się w Tbilisi, rozpoczęto rozmowy na temat utworzenia wspólnego batalionu sił pokojowych. Według gruzińskiego resortu obrony wspólny kontyngent mógłby brać udział w misjach pokojowych i humanitarnych pod auspicjami ONZ, OBWE, NATO, UE. Miano dyskutować nad rozwiązaniami prawnymi regulującymi działalność sił pokojowych GUAM, a także innymi kwestiami współpracy wojskowej. Według doniesień rosyjskiej prasy przedstawiciele Mołdawii wycofali się z rozmów w Tbilisi, motywując to zapisami konstytucji mówiącymi o neutralnym statusie kraju i zakazującymi udziału w blokach militarnych ${ }^{105}$. Szczyt w Baku w czerwcu 2007 r. poświęcono m.in. projektowi powołania batalionu pokojowego GUAM, który mógłby zostać rozmieszczony w miejscach konfliktów na terenie państw członkowskich GUAM ${ }^{106}$. Pomysł stworzenia własnych sił pokojowych został skrytykowany przez W. Woronina ${ }^{107}$. Pozbycie się sił rosyjskich i możliwość stworzenia własnego systemu bezpieczeństwa było dla tych państw jednym z głównych celów. Wielokrotnie składane deklaracje o solidarności i konieczności zapewnienia bezpieczeństwa w regionie okazały się jednak pustym frazesem w czasie wojny gruzińsko-rosyjskiej. Jedynie Ukraina wyraźnie opowiedziała się po stronie Gruzji - nie można jednak tego traktować jako oficjalnego stanowiska GUAM. Wstrzemięźliwość przywódców Azerbejdżanu i Mołdawii potwierdziła, że interesy członków GUAM w okresie długoterminowym są nie do pogodzenia ${ }^{108}$. Po doświadczeniach z 2008 r., kiedy państwa członkowskie przekonały się, że nie mogą uzależniać swojego bezpieczeństwa od pomocy zewnętrznej - państw zachodnich i USA - najlepszym wyjściem dla członków GUAM byłoby rozwijanie struktur bezpieczeństwa regionalnego za pomocą porozumień regionalnych, ale w ramach globalnego systemu zabezpieczeń. To chyba jednak jest niemożliwe do zrealizowania.

\section{Ropa, gaz a polityka}

Najlepszym mottem dla tych rozważań wydają się słowa amerykańskiego publicysty Thomasa L. Friedmana: „wraz ze wzrostem cen ropy przywódcy surowcowych państw są coraz mniej wrażliwi na to, co świat o nich myśli i mówi" ${ }^{109}$.

W sferze militarnej brak niezależności energetycznej jest uważany za jedno z głównych zagrożeń bezpieczeństwa państwa. Istniejąca zaś infrastruktura kom-

105 P. Świeżak, Gruzja/GUAM rozmawia o wspólnych siłach zbrojnych, http://www.psz.pl/index. php?option=content\&task=view\&id=3148 (dostęp 26 III 212).

106 W. Konończuk, op. cit.

107 GUAM/Prezydenci Polski i Litwy przybędą na szczyt, http://www.psz.pl/index.php?option=com_ content\&task=view\&id=11720 (dostęp 19 I 2012).

108 Również zagraniczni analitycy zastanawiają się, czy po wydarzeniach z sierpnia 2008 r. możliwa jest jeszcze przyszłość organizacji GUAM, zob. P. Goble, GUAM After Georgia: More Important than Ever or Soon to Die?, http://azer.com/aiweb/categories/caucasus_crisis/index/cc_articles/goble/ goble_2008/goble_special/goble_guam.html (dostęp 22 II 2012).

109 E. Wyciszkiewicz, Rosyjski sektor naftowo-gazowy - uwarunkowania wewnętrzne i perspektywy rozwoju,[w:] E. Wyciszkiewicz (red.), Geopolityka rurociagów. Współzależność energetyczna a stosunki międzypaństwowe na obszarze postsowieckim, Warszawa 2008, s. 40. 
pleksu paliwowo-energetycznego odziedziczona po ZSRR ogranicza w istotny sposób możliwość importu gazu spoza obszaru byłego ZSRR ${ }^{110}$.

Ukraina jest w zasadniczy sposób uzależniona od importu surowców energetycznych z Rosji lub za jej pośrednictwem z Azji Środkowej. Rosja natomiast zależy od tranzytu tych surowców przez ukraińskie terytorium - ok. 45\% rosyjskiej ropy eksportowanej do krajów europejskich płynie tranzytem przez Ukrainę. Rosji udało się również przejąć kontrolę nad niektórymi ukraińskimi kompleksami naftowymi, kontroluje cztery z sześciu wielkich ukraińskich rafinerii: w Chersonie, Łysyczańsku, Odessie i Kremenczugu. Elementem polityki zagranicznej W. Juszczenki była budowa na obszarze proradzieckim alternatywnych wobec Rosji sojuszy politycznych i energetycznych, m.in. Ukraina wraz z Polską, Azerbejdżanem, Gruzją i Litwą planowały stworzenie nowego korytarza transportu ropy naftowej z regionu Morza Kaspijskiego do odbiorców europejskich. Projekt Euroazjatyckiego Korytarza Ropy Naftowej omawiany był za prezydentury W. Juszczenki na czterech szczytach energetycznych ${ }^{111}$. Uniezależnieniem się od rosyjskiej ropy miał być dla Ukrainy projektowany rurociąg Odessa-Brody-Płock. Umożliwiłby Ukrainie i Polsce import ropy $\mathrm{z}$ basenu Morza Kaspijskiego. Rosji udało się jednak doprowadzić do odwrócenia kierunku przesyłu rurociągiem Odessa-Brody, by służył on do importu na Ukrainę ropy rosyjskiej ${ }^{112}$. Do $2001 \mathrm{r}$. Rosja była największym eksporterem gazu na Ukrainę. Zastąpił ją Turkmenistan, ale sprowadzany z niego gaz płynie przez terytorium Rosji, w efekcie czego zarówno wielkość dostaw, jak i cena na granicy zależą od uzgodnień rosyjsko-ukrańskich. Turkmenistan ze względu na nieprzewidywalność reżimu też nie jest wiarygodnym partnerem.

Rosja dąży do przejęcia kontroli nad ukraińskim kompleksem gazowym lub znalezienia alternatywnego rozwiązania, które pozwoliłoby jej eksportować gaz do europejskich odbiorców z pominięciem Ukrainy (podkradającej rosyjski gaz eksportowany na Zachód). Ukraina nie ma obecnie możliwości uniezależnienia się od Rosji w kwestii dostaw gazu ze względu na pozycję tego kraju w sektorze gazowym w Azji Środkowej (Turkmenistan, Uzbekistan i Kazachstan są coraz bardziej uzależnione od Rosji) oraz tranzytowe położenie Rosji ${ }^{113}$.

Również Gruzja zależna jest od dostaw rosyjskiego gazu. Rosyjska polityka gazowa w stosunku do Gruzji miała służyć utrzymywaniu zależności od dostaw taniego surowca i przejmowania aktywów energetycznych i infrastruktury. Gruziński sektor elektroenergetyczny znalazł się pod kontrolą rosyjskiego monopolisty RAO JES, który przejął udziały w licznych spółkach dystrybucyjnych oraz elektrowniach ${ }^{114}$.

110 A. Szeptycki, Stosunki między Federacją Rosyjska a Ukraing w sektorze gazowym, [w:] E. Wyciszkiewicz (red.), Geopolityka rurociąów..., s. 101-102.

111 Rusza szczyt energetyczny w Baku, http://www.money.pl/gospodarka/wiadomosci/artykuł/rus za;szczyt;energetyczny;w;baku;166,0,384934.html (dostęp 18 II 2012).

112 A. Szeptycki, op. cit., s. 100.

113 Ibidem, s. 121-123.

114 E. Wyciszkiewicz, Rosyjska polityka energetyczna w basenie Morza Kaspijskiego, [w:] E. Wyciszkiewicz (red.), Geopolityka rurociagów..., s. 179. 
Kiedy w 2003 r. Gazpromowi udało się wkroczyć na gruziński rynek (gruzińskie grupy interesu wspierały ekspansje rosyjskiego kapitału, licząc na zyski), podstawowym celem rosyjskich działań stało się przejęcie magistrali gazowej, aby mieć kontrolę nad osią gazową Północ-Południe, uzyskać możliwość nowej współpracy z Iranem i utrudnić realizację projektu Baku-Tbilisi-Eszurum. Aby zmniejszyć zależność od Rosji, należy zmienić kontrakty dotyczące odbioru gazu z BTE tak, aby Azerbejdżan stał się dostawcą dominującym. Według umów głównym odbiorcą gazu z tego gazociągu ma być Turcja, natomiast Azerbejdżan i Gruzja mają dostać mniejsze ilości gazu w ramach usług tranzytowych ${ }^{115}$. Zarówno Azerbejdżan, jak i Gruzja dążą do najszybszego i całkowitego uwolnienia się od dostaw gazu z Rosji. W sytuacjach kryzysowych - kiedy nie mogą dojść do porozumienia w sprawie ceny sprowadzanego $\mathrm{z}$ Rosji gazu bądź gdy dostawy są przez Rosję przerywane np. $\mathrm{z}$ powodu ataków na gazociąg w południowej Rosji - posiłkują się krótkoterminowymi dostawami $z$ Iranu ${ }^{116}$.

Uzależniona od rosyjskiego gazu jest również Mołdawia, a z powodu swojego położenia geograficznego jest też istotna dla Rosji w transporcie surowców w kierunku Bałkanów. Rosji udało się przejąć kontrolę nad siecią przesyłową w Mołdawii, sprawuje tam całkowitą kontrolę nad sektorem gazowym i elektrycznym ${ }^{117}$. Dzięki zależności Mołdawii i Naddniestrza od rosyjskich dostaw gazu, obecności rosyjskiego kapitału w szeregu strategicznych przedsiębiorstw tego regionu oraz obecności w regionie swojego kontyngentu sił zbrojnych, Rosja wywiera polityczne naciski i skutecznie mąci w uregulowaniu konfliktu naddniestrzańskiego (przy oficjalnych deklaracjach poparcia i zaangażowania w jego rozwiązanie). W takcie wizyty w Naddniestrzu i Mołdawii w maju 2008 r. przewodniczącego komisji ds. WNP i kontaktów z rodakami rosyjskiej Dumy Aleksieja Ostrowskiego władze w Kiszyniowie usłyszały, że Rosja życzy sobie, aby Mołdawia wystąpiła z GUAM, które jest postrzegane w Moskwie jako struktura antyrosyjska ${ }^{118}$. Poprzez rosnące ceny surowców oraz kwestie spłaty zaległości za gaz już dostarczony (w przypadku Ukrainy i Mołdawii) Rosja staje się tym, kto rozdaje karty ${ }^{119}$. Konsekwencje takiej sytuacji mogą odczuć odbiorcy gazu w UE. Rozwiązaniem tej sytuacji jest uniezależnienie się od rosyjskich surowców przez wszystkich członków GUAM. Dywersyfikacja powinna dotyczyć surowców oraz szlaków transportowych. Jest to

115 Ibidem, s. 179-181.

116 Ibidem, s. 179-181.

117 P. Wróbel, Wplyw Rosji na wspótczesne bezpieczeństwo energetyczne Unii Europejskiej, [w:] J. M. Fiszer (red.), Polska w Unii Europejskiej. Aspekty polityczne, międzynarodowe, społeczno-gospodarcze i wojskowe, Warszawa 2009, s. 314-315.

118 Nowe elementy $w$ rosyjskim stanowisku wobec konfliktu $w$ Naddniestrzu - komentarz OSW, http://www.osw.waw.pl/pl/publikacje/tydzien-na-wschodzie/2008-06-04/nowe-elementy-w-rosyjskim-stanowisku-wobec-konfliktu-w-nadniestrzu (dostęp 19 I 2012).

119 O rosyjskiej polityce surowcowej wobec członków WNP pisze szeroko również M. Olesińka, Egzemplifikacja politycznych uwarunkowań strategii marketingowe koncernu energetycznego Gazprom w relacjach $z$ krajami WNP, http://szczesniak.pl/files/olesinska_gazprom_polityka_strategia_marketingowa_WNP.pdf (dostęp 20 III 2012). 
zarówno w interesie wyżej wymienionych krajów, jak również UE i USA, ale czy organizacja GUAM ma tu rzeczywiście większe znaczenie? Czy nawet wykorzystując kwestie bezpieczeństwa energetycznego, jest ona w stanie uzyskać konkretne silne poparcie na arenie międzynarodowej?

Państwa europejskie z USA na czele realizują głównie interesy ekonomiczne i jako ich konsekwencje wzmacniają swoją pozycję polityczną na obszarze euroazjatyckim. Ale dla państw Kaukazu Południowego jest to w bardzo dużym stopniu szansa na uzyskanie poparcia koniecznego dla realizacji swoich zasadniczych dążeń politycznych. Uruchomienie nowej infrastruktury przesyłu ropy naftowej (ropociąg Baku-Tbilisi-Ceyhan ${ }^{120}$ ) i gazu (Baku-Tbilisi-Eszurum) włączyło kraje Zakaukazia w sieć strategicznych powiązań gospodarczych i politycznych z rynkami zachodnimi, ale nie dało to aż tak dużego jak oczekiwano impulsu do rozwoju gospodarczego regionu. Na szczycie energetycznym GUAM w Kijowie 23 V 2008 r., kiedy omawiano kwestie naftociągu Odessa-Brody z przedłużeniem do Europy, przedstawiciele Azerbejdżanu uchylili się od odpowiedzi, czy kraj ten jest w stanie zabezpieczyć ten projekt odpowiednią ilością ropy naftowej. Eksperci azerscy wskazują, że długoterminowe kontrakty zobowiązują Azerbejdżan do dostaw ropy naftowej, przez co nie posiada on odpowiednich nadwyżek surowca ${ }^{121}$. Wszystkie kraje członkowskie GU(U)AM były zainteresowane trasami przesyłowymi ropy naftowej. To zarazem je jednoczyło, ale mogło też dzielić. W 2002 r. prezydent Mołdawii W. Woronin oświadczył, że jego kraj będzie brał udział w pracach organizacji GUUAM, kierując się przede wszystkim własnymi interesami, dążąc do tego, aby gaz i ropa z rejonu kaspijskiego płynęły do Europy przez terytorium Mołdawii, nie godząc się tym samym na bardziej ekonomiczny kierunek ukraiński. Trzymając się swojej strategii, zapowiedział, że nie będzie uczestniczyć w kolejnym szczycie w Jałcie w 2003 roku ${ }^{122}$.

Wszystkie państwa należące do GU(U)AM brały udział we współfinansowanym przez Unię Europejską projekcie TRACECA, lecz, niestety, nie zaowocowało to utworzeniem ponadnarodowych struktur. Za największymi inwestycjami, jak budowa ropociągu Baku-Tbilisi-Ceyhan i gazociągu Baku-Tbilisi-Eszurum poszła budowa transregionalnej linii kolejowej z Karsu przez Tbilisi do Baku, co wzmocniło wzajemną współpracę między Turcją, Gruzją i Azerbejdżanem ${ }^{123}$. Kolej Baku-Tbilisi-Kars ma otwierać najkrótszy korytarz do Azji Środkowej, alternatywnej żelaznej drogi przez Iran ${ }^{124}$. Kolej ta, według doniesień rosyjskiej agencji informacyjnej „RosBalt”,

120 Otwarty 25 V 2005 r. - w uroczystości wzięli udział prezydenci Azerbejdżanu, Gruzji i Turcji oraz minister energetyki USA.

121 Decyzje Azerbejdżanu w tej kwestii będą uzależnione od konkretnych korzyści ekonomicznych i politycznych, P. Andrusieczko, op. cit., s. 49.

122 V. Dunaeva, op. cit., s. 78.

123 P. Adamczewski, Geopolityczne znaczenie Azerbejdżanu, [w:] J. Marszałek-Kawa (red.), Strategie w polityce azjatyckiej. Rozważania o możliwościach współczesnej Azji, Toruń 2011, s. 138.

${ }^{124}$ L. Papuashvili, Geopolityczne położenie Gruzji a rozwój ekonomiczny kraju, [w:] J. Marszałek-Kawa (red.), Wartości azjatyckie, polityka i prawa człowieka, Toruń 2010, s. 309. 
ma być oddana do eksploatacji w 2013 roku $^{125}$. Inne projekty dotyczące transportu kolejowego są zawarte w Europejskiej Polityce Sąsiedztwa (EPS) i są popierane przez wszystkich czterech członków GUAM. Unia współfinansowała również projekt INOGATE (Intrastate Oil Gas Transport to Europe). Wprawdzie Unia Europejska jest zainteresowana nowymi inwestycjami w regionie Morza Kaspijskiego i wspiera budowę gazociągów dla przesyłu surowców do Europy i Chin, to jednak ograniczenie tych inwestycji ze względu na dużą liczbę państw, z którymi trzeba podpisać umowy, złożoność finansowania inwestycji i niepewność co do wielkości przyszłego popytu powoduje w dużym stopniu niemożność uzyskania stawianych celów. Przykładem może być chociażby plan budowy gazociągu „Nabucco”, który do tej pory nie zaczął być realizowany. Według podjętych w styczniu 2011 r. decyzji, na które w dużym stopniu miała wpływ Turcja, został skrócony (miał biec z Azerbejdżanu przez Turcję, Bułgarię, Rumunię i Węgry do Austrii) i ma transportować tylko połowę z zakładanych w planie 31 miliardów metrów sześciennych gazu rocznie ${ }^{126}$.

Przedłużające się negocjacje w sprawie rozpoczęcia jego budowy wykorzystała Rosja. W październiku 2009 r. rosyjski Gazprom i azerbejdżański SOCAR podpisały kontrakt na dostawę gazu ziemnego z Azerbejdżanu do Rosji ${ }^{127}$. Dostawy rozpoczęły się 1 I 2010 roku. Początkowo wyniosą 500 milionów metrów sześciennych rocznie. W przyszłości mają być większe, gdyż strona rosyjska deklaruje chęć kupna w tym kraju 1,5 miliarda metrów sześciennych gazowego paliwa. W celu realizacji umowy konieczne było wprowadzenie modyfikacji w gazociągu Kazi-Magomed-Mozdok i odwrócenie kierunku tłoczenia surowca. Tym samym wznowiona została współpraca azerbejdżańsko-rosyjska w sektorze gazowym ${ }^{128}$. Podpisanie porozumienia jest wyrazem zniecierpliwienia władz w Baku brakiem ostatecznej decyzji UE odnośnie do realizacji „Nabucco”. Wobec niemożności osiągnięcia porozumienia, część koncernów rozważa wycofanie się z konsorcjum „Nabucco” (m.in. niemiecki koncern RWE). Pozostaje pytanie, czy w ogóle on powstanie ${ }^{129}$ ? Strona azerska kilkakrotnie ostrzegała Brukselę o możliwym skierowaniu swojego gazu do azjatyckich odbiorców, m.in. Chin. Rosja nie pozostaje bierna, o czym świadczy konkurencyjny wobec „Nabucco” rosyjski plan budowy gazociągu „Południowy Potok” (South Stream), który ma na celu zaopatrzenie w gaz tych samych odbiorców. Udziały w realizacji projektu Rosja zaproponowała Ankarze w celu odciągnięcia jej od realizacji

125 Gruzja Omijając Rosję, http://www.kresy.pl/publicystyka,analizy?zobacz/gruzja-omijajac-rosje (dostęp 26 VI 2012).

126 Gazociąg Nabucco będzie tańszy i krótszy, http://forsal.pl/artykuly/597900,gazociag_nabucco_bedzie_krotszy_i_tanszy.html (dostęp 10 III 2012).

127 Zwraca się uwagę, że na decyzję tę wpływ miało również polepszenie się stosunków turecko-armeńskich (umowa z 10 X 2009). Aby nie zostać osamotnionym przed ostatecznym uregulowaniem konfliktu karabaskiego, Azerbejdżan stara się zacieśnić swoje stosunki z Rosją - głównym sojusznikiem Armenii.

128 P. Adamczewski, op. cit., s. 133-134.

129 RWE może porzucić budowe gazociagu Nabucco,http://wyborcza.biz/biznes/1,100896,10986209, RWE_moze_porzucic_budowe_gazociagu_Nabucco_html (dostęp 10 III 2012). 
„Nabucco"130. Gazociąg, który Gazprom zamierza ułożyć z włoskim Eni, ma być oddany do eksploatacji w 2015 roku. Magistralą tą planuje się przesyłać 63 miliardów metrów sześciennych gazu rocznie ${ }^{131}$.Jeszcze mniej realna wydaje się szansa powstania planowanego w rejonie nadkaspijskim gazociągu Gruzja-Ukraina-Unia Europejska (nazwanego White Stream), którym gaz ze złóż azerskich, a w przyszłości turkmeńskich i kazachskich, ma być transportowany do UE ${ }^{132}$. Rosja nieustannie lobbuje w Gruzji i na Ukrainie, przekonując do braku zasadności dla zaangażowania w projekt White Stream ${ }^{133}$.

Problematyczna staje się rola Ukrainy jako państwa tranzytowego ${ }^{134}$. Kryzys gazowy z 2006 r. i podejrzenia o przechwytywanie przez stronę ukraińską części dostaw, które miały być przeznaczone dla państw członkowskich UE, a także zmiana sytuacji politycznej i nastrojów na Ukrainie czynią z tego kraju coraz mniej wiarygodnego partnera. Podpisanie przez prezydentów Janukowycza i Miedwiediewa 21 IV 2010 r. w Charkowie wspólnego porozumienia odebrane zostało jako wyznacznik nowego etapu rozwoju relacji rosyjsko-ukraińskich. Ukraina za cenę wyrażenia zgody na przedłużenie do 2042 r. stacjonowania na Krymie Floty Czarnomorskiej Federacji Rosyjskiej otrzymała od Rosji tańszy gaz (studolarową zniżkę odliczaną od kwoty 330 dolarów za tysiąc metrów sześciennych gazu do roku 2019) ${ }^{135}$. W połowie maja 2012 r. premier Ukrainy Mykoła Azarow oświadczył, że tzw. „porozumienie charkowskie” w rzeczywistości nie przyniosło Ukrainie obniżenia ceny gazu i że ukraiński rząd cały czas bezskutecznie domaga się dotrzymania w tej kwestii umowy ${ }^{136}$. Kwestie energetyczne zaczynają na Ukrainie odgrywać priorytetowe role i to one stopniowo przewartościowują politykę obozu prezydenta Janukowycza. W odpowiedzi na projekt South Stream Janukowycz odrzucił ofertę Unii Celnej i związanej z nią zniżki cen surowca oraz zdecydował się na budowę gazoportu obok Odessy i zmniejszenie kontraktów wiążących import gazu z Rosji. Ukraina zainteresowana jest połączeniem

130 P. Adamczewski, op. cit., s. 135-136.

131 E. Kustra, Zakaukazie a dywersyfikacja dostaw surowców przez UE i USA, http:// www.psz.pl/ Zakaukazie-a-dywersyfikacja-dostaw-surowcow-przez-UE-i-USA (dostęp 10 III 2012).

132 Szerzej na temat planów tych inwestycji w regionie Morza Kaspijskiego D. Niedziółka, Bezpieczeństwo energetyczne na obszarze poradzieckim, [w:] A. Bryc, A. Legucka, A. Włodkowska-Bagan (red.), op. cit., s. 291-292.

133 Ibidem, s. 292.

134 Rosja pozbyła się pośrednictwa krajów tranzytowych, otwierając 8 XI 2011 r. pierwszą nitkę Gazociągu Nord Stream (z Rosji do Niemiec przez Morze Bałtyckie).

135 Przed podpisaniem porozumienia w ukraińskich mediach pojawiły się informacje o negocjacjach dotyczących obniżenia ceny rosyjskiego gazy w zamian za oddanie Rosji $80 \%$ potężnych magazynów gazowych wzdłuż zachodniej granicy Ukrainy. W ten sposób Rosja zabezpieczyłaby sobie ciągłość dostaw gazu dla Europy Zachodniej do czasu budowy alternatywnych korytarzy gazowych, niezależnie od relacji gazowych z Ukrainą. P. Andrusieczko, Flota za gaz, http://www.new.org. pl/2010-05-01,flota_za_gaz.html (dostęp 22 VI 2012).

136 Porozumienie charkowskie może zostać unieważnione, http://www.studium.uw.edu.pl/?post/ 13360 (dostęp 22 VI 2012). 
z Gazociągiem Transanatolijskim i udziałem w azersko-gruzińsko-rumuńskim interkonektorze, który pozwoli transportować skroplony gaz z Morza Kaspijskiego do Europy ${ }^{137}$. Ukraina szuka coraz mocniejszego porozumienia z Azerbejdżanem, a dzięki temu zaczyna na nowo zaznaczać swoją obecność w GUAM.Zupełnie inne pytanie, ale równie ważne i dające do myślenia wszystkim zaangażowanym w te projekty, dotyczy zapewnienia bezpieczeństwa rurociągom, przez które mają być transportowane złoża. Że jest to sprawa istotna zwłaszcza dla państw kaukaskich, najlepiej świadczy lekcja dana przez Rosję w czasie wojny gruzińsko-rosyjskiej 2008 roku. Po ogłoszeniu przez prezydenta Miedwiediewa „wstrzymania operacji wojskowej”, rosyjskie wojska nadal okupowały Gori (przez które przechodzi rurociąg Baku-Supsa) i Poti. Niszczyły gruziński terminal naftowy w Poti oraz pociągi i infrastrukturę kolejową wraz z mostami wykorzystywanymi do transportu ropy naftowej w innych rejonach Gruzji ${ }^{138}$.Zaproponowany na szczycie GUAM w Batumi projekt utworzenia międzynarodowego centrum jakości i ilości rosyjskiego gazu przesyłanego przez Ukrainę do UE rosyjska „Niezawisimaja Gazieta” skomentowała słowami - „GUAM chce zostać unijną dyspozytornią” (gazu - R.K.-M.) ${ }^{139}$. Rosja nadal jest postrzegana jako naftowy gigant i dlatego też polityka państw Zachodu wobec niej nie jest jednakowa. A zawarta $16 \mathrm{IV}$ 2012 r. umowa między Exxon Mobil - liderem amerykańskiej branży paliwowej - a rosyjskim gigantem Rosnieftem na wspólną eksploatacje złóż ropy naftowej i gazu spod dna Morza Karskiego w Arktyce i Morza Czarnego raczej nie rokuje dobrze inwestycjom Europejsko-Kaukasko-Azjatyckim ${ }^{140}$. Już w 2008 r. gruziński ekspert Giorgi Chuchaszwili pisał, że chęć uczestniczenia członków GUAM $\mathrm{w}$ procesie umocnienia bezpieczeństwa energetycznego Europy jest zrozumiała, lecz „wszystkie atuty są w ręku Rosji”. Toteż utworzenie adekwatnej przeciwwagi przez GUAM, która ma niewielkie zasoby, jest rzeczą niemożliwą ${ }^{141}$.

Kontakty z państwami tranzytowymi surowców energetycznych prowadzone są przez UE przede wszystkim w ramach Europejskiej Polityki Sąsiedztwa. Obejmuje ona całokształt spraw politycznych, bezpieczeństwa, ekonomicznych, handlowych i współpracę energetyczną. Nakierowana jest na rozwijanie współpracy zgodnie z unijnymi standardami i wspieranie demokratyzacji reform wolnorynkowych. Oferuje pomoc finansową i techniczną w osiąganiu celów wyznaczonych w umowach bilateralnych z poszczególnymi państwami w ramach EPS.

137 P. A. Maciążek, Powinniśmy kibicować zwycięstwu niebieskich, http://politykawschodnia.pl/ index.php/2012/10/28/maciozek-powinnismy-kibicowac-zwyciestwu-niebieskich-wybory-na-ukrainie (dostęp 6 II 2013).

138 P. Wipler, Rosyjska lekcja geopolityki, „Obserwator. Biuletyn Biura Bezpieczeństwa Narodowego”, s. 22-23, http://www.bbn.gov.pl/palm/pl/501/1497/OBSERWATOT.BBN.html (dostęp 10 III 2012).

139 „Niezawisimaja Gazeta” - GUAM chce zostać unijna dyspozytornia gazu, http://wiadomosci. gazeta.pl/wiadomosci/1,114873,5414028.html (dostęp 17 IV 2012).

140 Jest to niezwykle ważna umowa, pierwszy raz bowiem w dziejach rosyjska państwowa kampania naftowa zostanie dopuszczona do eksploatacji złóż w Ameryce Północnej. Takiego przywileju Waszyngton odmówił np. Chińczykom. A. Kublik, Łupki za Arktykę, „Gazeta Wyborcza”, 18 IV 2012, s. 1.

141 „Niezawisimaja Gazeta” - GUAM chce zostać unijną dyspozytornią gazu... 
Europejską Polityką Sąsiedztwa objęci są wszyscy członkowie GUAM ${ }^{142}$. Jednak UE zainteresowana była początkowo Ukrainą i Mołdawią, a dopiero na początku XXI w. wykazała zainteresowanie krajami Zakaukazia ze względu na położenie geopolityczne i geoekonomiczne (od czerwca 2004 r. EPS są objęte Azerbejdżan, Gruzja i nienależąca do GUAM Armenia) ${ }^{143}$. Dla UE nie stanowiło chyba większej przeszkody to, że Azerbejdżan jest systematycznie krytykowany za nieprzestrzeganie praw człowieka ${ }^{144}$. W listopadzie 2006 r. przyjęto tzw. Plany Działania współpracy UE i poszczególnych państwa na najbliższe pięć lat. Dotyczą wzmacniania demokracji, praw człowieka, zasad praworządności, reform gospodarczych-walki z ubóstwem, reformy systemu celnego i podatkowego, współpracy regionalnej, współpracy międzynarodowej m.in. w dziedzinie energetycznej, bezpieczeństwa, wspólnych działań na rzecz rozwiązania konfliktów zbrojnych ${ }^{145}$. Jak twierdzą rzeczoznawcy, EPS jest coraz mniej skuteczna. Dla członków GUUAM chyba szczególnie istotne było to, że nie udało się rozciągnąć wspólnoty bezpieczeństwa na obszary sąsiedztwa i jak pokazała rzeczywistość UE nie ma odpowiednich środków i możliwości, aby rozwiązać spory w obszarze wschodniego sąsiedztwa ${ }^{146}$. Bardziej skuteczną formą EPS miało być Partnerstwo Wschodnie, którego inicjatorem utworzenia była Polska. W jej interesie jest bowiem wzmacnianie ram współpracy UE z państwami wschodnimi ze względu na posiadanie wspólnych interesów: gospodarczych, energetycznych (przedłużenie rurociągu Odessa-Brody do Płocka, kaspijsko-czarnomorski korytarz gazowy) i bezpieczeństwa (tzw. wschodni wymiar Paktu Północnoatlantyckiego) ${ }^{147}$. Polska podnosi kwestie solidarności energetycznej państw członkowskich UE w obszarze gazu ziemnego i ropy naftowej. Ma ją zapewnić międzynarodowa polityka energetyczna aktywnie wspierająca europejskie interesy. W zawieranych z Rosją umowach międzynarodowych należy uwzględnić możliwość wzajemnej liberalizacji warunków handlu i inwestowania w rynki poszukiwań i wydobycia surowców oraz handlu detalicznego i dystrybucji oraz kwestie dostępu do rurociągów w krajach położo-

${ }^{142}$ Szerzej na ten temat zob. A. Staszczyk (red.), Europa Wschodnia i Kaukaz Południowy w polityce Unii Europejskiej, Szczecin 2011.

${ }^{143}$ K. Strachota, Kraje Południowego Kaukazu (Armenia, Azerbejdżan, Gruzja), [w:] J. M. Fiszer (red.), Sytuacja wewnętrzna w krajach postkomunistycznych Europy i Azji oraz ich polityka międzynarodowa w latach 2006-2007, Warszawa 2007, s. 88.

144 A. Orzelska, op. cit., s. 140.

145 K. Strachota, op. cit., s. 88-89.

146 Ukraińscy eksperci uważali, że przyczyn braku odpowiedniego wsparcia GUAM ze strony Brukseli należy szukać w relacjach Rosji z UE i zależności Europy od rosyjskich dostaw gazu i ropy. Oprócz tego w UE przeważała opinia, że projekt GUAM był inicjowany przez USA i znajdował się pod silnym wpływem Waszyngtonu. P. Andrusieczko, Perspektywy alternatywnych organizacji..., s. 47.

${ }^{147}$ Polska aktywnie zabiega o nadanie EPS większego zróżnicowania nie tylko w indywidualnych stosunkach z państwami, ale też na poziomie regionalnym. E. Kużelewska, Partnerstwo Wschodnie jako specyficzna forma Europejskiej Polityki Sasiedztwa, [w:] J. Diec (red.), Rozpad ZSRR i jego konsekwencje dla Europy i świata, część III Kontekst międzynarodowy, Kraków 2011, s. 304. 
nych wzdłuż szlaków tranzytowych i transportowych ${ }^{148}$. Na ile jednak UE może być konkretnym wsparciem dla interesów członków GUAM objętych Europejską Polityką Sąsiedztwa i Partnerstwa Wschodniego? Można zaryzykować stwierdzenie, że UE zdecydowała się na objęcie Europejską Polityką Sąsiedztwa Gruzji i Azerbejdżanu ze względu na swoje własne interesy. Wszak od przyjętych żąda się wzmacniania demokracji, przestrzegania praw człowieka i zasad praworządności, a Azerbejdżan nie może się tym poszczycić i co gorsza nadal niewiele się tam zmienia. Od samego początku widoczne było uprzywilejowanie UE wobec państw objętych polityką sąsiedztwa. Formuła negocjacji akcesyjnych miała przede wszystkim charakter jednokierunkowy - to państwo kandydujące było zobowiązane do spełnienia szeregu warunków celem uzyskania członkostwa ${ }^{149}$. Równie istotne jest to, że w relacjach z UE pozycja państw objętych Partnerstwem Wschodnim jest o wiele słabsza niż Rosji. Idea Partnerstwa Wschodniego nie zmieniła w większym stopniu dotychczasowej polityki Unii Europejskiej wobec państw objętych jej wpływami. Obecnie niektórzy z analityków zastanawiają się, czy też poprzez ustanowienie Europejskiej Polityki Sąsiedztwa Unia Europejska dąży do ustalenia regulacji z jej sąsiadami na granicach zewnętrznych, czy też zakłada zakończenie procesu integracji europejskiej ${ }^{150}$. Skoro Unia Europejska nie ma możliwości ani woli rozwiązywania problemów państw objętych Europejską Polityką Sąsiedztwa, to tym bardziej nie będzie tego czynić we wspieraniu na arenie międzynarodowej organizacji GUAM. Od początku mogła ona liczyć ze strony Zachodu, jak i USA tylko na słowne deklarację i pieniądze. Wydarzenia z 2008 r., kiedy okazało się, że nikt nie chce umierać za Gruzję (Zachód nie wprowadził nawet sankcji ekonomicznych ${ }^{151}$ ), pokazały, że w przyszłości raczej nic się nie zmieni.

\section{Co dalej?}

Przeanalizowanie historii GUAM pokazało, że rację miał Janusz Korwin-Mikke, oceniając w 2006 r., że GUAM „będzie raczej deklaracją intencji, niż realnym blokiem"152.Państwowości członków GUAM są jeszcze nie w pełni stabilne i cały czas podatne na wpływy. Rosja nadal może wykorzystywać różne środki nacisku na państwa członkowskie GUAM (popieranie ruchów separatystycznych w Gruzji ${ }^{153}$

148 C. T. Szyjko, Nowy wymiar dialogu energetycznego UE-Rosja z perspektywy priorytetów polskiej prezydencji, [w:] A. Bryc, A. Legucka, A. Włodkowska-Bagan (red.), op. cit., s. 330.

149 E. Kużelewska, op. cit., s. 301.

150 Ibidem, s. 308.

151 Jedyną inicjatywą było wysłanie przez UE do Gruzji Misji Obserwacyjnej EUMM (European Union Monitoring Mission in Georgia), której efektem było zaprzestanie przemocy zbrojnej, względna stabilizacja i przestrzeganie praw człowieka. A. Ciupiński, op. cit., s. 141-143.

152 J. Korwin-Mikke, GUAM w Eurazji, „Najwyższy Czas”, R. XVII, nr 21 (836) 27 maja 2006, s. XX.

153 Rosji udało się dopiąć celu i nie dopuścić do reintegracji z Gruzją zbuntowanych prowincji. Rosja uznała Abchazję i Osetię za niepodległe państwa (25 VIII 2008 r. - Rada Federacji, 26 VIII prezydent) i ustanowiła specjalne strefy bezpieczeństwa dla zabezpieczenia nowych państw od działań odwetowych Gruzji. Przed uznaniem powstrzymali się nawet najbliżsi sojusznicy Moskwy - w tym republiki byłego ZSRR i Chiny . 
i Mołdawii, silna pozycja eksportera surowców energetycznych, wobec którego Mołdawia i Ukraina są bardzo zadłużone, poprzez rosyjskie lobby ekonomiczne, które ma ogromny udział w prywatyzacji poszczególnych przedsiębiorstw w krajach członkowskich czy poprzez miejscową mniejszość rosyjską, zwłaszcza na Ukrainie ${ }^{154}$ ). Tylko jednoznaczne poparcie Zachodu i rzeczywista, a nie symboliczna obietnica członkostwa w UE i NATO, mogą pomóc tym krajom w budowaniu struktur niezależnych od Rosji. Jednak żadne z mocarstw regionalnych czy globalnych nie może stać się gwarantem funkcjonowania GUAM, ponieważ wszystkie współpracują z tą organizacją tylko doraźnie i to po to, aby osiągnąć dla siebie jak największe korzyści. Dla UE GUAM jednak stopniowo tracił wiarygodność jako organizacja, której celem zgodnie z Deklaracją Kijowską było „wzmacnianie demokracji, przestrzeganie rządów prawa oraz respektowanie podstawowych praw człowieka i wolności”155. Wydarzenia na Ukrainie i w Gruzji w 2007 r. oraz w Mołdawii w 2009 i konsekwenthe umacnianie dyktatury Ilhama Alijewa w Azerbejdżanie są przykładem, że były to kolejne nic nieznaczące deklaracje.

Wszystkie podejmowane przez państwa GUAM wspólne inicjatywy ekonomiczne mające na celu powiązanie tego regionu z gospodarką światową będą się nadal kończyły połowicznymi sukcesami, dopóki będą istniały nierozstrzygnięte kwestie Naddniestrza, Abchazji, Osetii Południowej oraz Górskiego Karabachu. Dotychczasowe działania Grupy Mińskiej oraz brak zdecydowanej reakcji państw zachodnich na wydarzenia z sierpnia 2008 r. mogą w przyszłości doprowadzić do rozszerzenia się napięć etnicznych również na inne kraje, co spowoduje wzmocnienie pozycji Rosji na terenie byłego ZSRR.

Różne są też plany i cele poszczególnych członków GUAM. Dla części polityków mołdawskich członkostwo tego kraju w GUAM stanowi jeden z planów integracji z UE. Jako jedno z najbiedniejszych państw europejskich Mołdawia potrzebuje poparcia w rozwoju społecznym i ekonomicznym. Jednak według niektórych analityków mołdawskich nie ma ona żadnych postaw, aby zdobyć pełną niezależność od państw, z którymi związała ją geopolityka i gospodarka (czyli Rosją - R.K.-M.). Mołdawia na początku unikała angażowania się w pracę organizacji. W. Woronin po objęciu stanowiska w $2001 \mathrm{r}$. nie tylko akcentował wagę współpracy z Rosją, ale też zgłaszał nawet chęć wstąpienia do ZBiR-u ${ }^{156}$. Od 2005 r. Mołdawia starała się odgrywać znaczącą rolę (z przerwami) w GUAM, a tymczasem dla społeczeństwa mołdawskiego słowo GUAM nic nie znaczy. Większość obywateli mołdawskich nie interesuje się tą wspólnotą ${ }^{157}$. Niektórzy z mołdawskich politologów uważają, że mglista jest „trwała przyszłość samego GUAM”158. Zaangażowanie Mołdawii w GUAM było chwilowe. Mołdawia unika konfrontacji z Moskwą. Obecnie znowu

${ }^{154}$ Przykładem takiej polityki była kwestia statusu języka rosyjskiego w Autonomicznej Republice Krymu czy próba wciągnięcia Ukrainy do ZBiR-u.

155 D. Kałan, op. cit.

156 A. Myśliwy, op. cit., s. 139.

157 V. Dunaeva, op. cit., s. 79.

158 „Niezawisimaja Gazeta” - GUAM chce zostać unijna dyspozytornia gazu... 
wykazuje zainteresowanie GUAM, ale „nie wiadomo jaka będzie przyszłość tego dziwnego państwa, które jest bardziej tworem przypadku niż woli narodu"159. Nie ma pewności, czy Ukraina i Gruzja nie wystąpią w przyszłości z GUAM lub nie skażą go na śmierć, gdy dostrzegą dla siebie większe szanse w innych blokach i porozumieniach. Wiktor Janukowycz jeszcze przed drugą turą wyborów na Ukrainie stwierdził, że GUAM jest „organizacją pozbawioną sensu” ${ }^{160}$. Objęcie przez niego władzy doprowadziło do marginalizacji GUAM. Najważniejszym czynnikiem konsolidującym GUAM i podstawą jego istnienia jest, jak słusznie zauważyła Agnieszka Myśliwy, zasobność Azerbejdżanu (a wcześniej również Uzbekistanu) w ropę naftową i gaz ${ }^{161}$. Chęć sprzedawania gazu po cenach rynkowych i dostęp do dywidend z opłat tranzytowych może jednak także doprowadzić do osłabienia współpracy w ramach organizacji (przykład „Nabucco” może być tylko preludium). Szansą dla państw członkowskich GUAM jest pośrednictwo w handlu między Europą a rozwijającą się w ogromnym tempie Azją Południowo-Wschodnią, przede wszystkim z Chinami i Indiami. Na korzyść organizacji działa także położenie geograficzne, które można wykorzystać zarówno przy przesyłaniu surowców, jak również budując drogi, linie kolejowe, lotniska, połączenia telekomunikacyjne, według planu, który pozwoli państwom GUAM przejąć kontrolę nad tranzytem innych towarów. Gdyby udało się całkowicie uniezależnić od Rosji i ustabilizować wewnętrznie, przy posiadaniu wolnej strefy handlowej i pewnych sojuszników, GUAM mógłby stać się perspektywą dla byłych republik radzieckich, które próbują znaleźć alternatywę dla dominacji rosyjskiej. To wymaga jednak od państw GUAM ścisłego przestrzegania wypełniania założonego planu współpracy bez ulegania jakimkolwiek naciskom ${ }^{162}$.

Niewielkie szanse powodzenia organizacji dają eksperci wywodzący się z krajów członkowskich. Według mołdawskiej dziennikarki Victorii Dunaevej GUAM „stał się dziwnym tworem, który ani na dobre narodzić się nie może, ani umrzeć nie ma ochoty"163. Prezydent Mołdawii W. Woronin zapytany w 2009 r. o perspektywy, oznajmił, że uważa GUAM jako organizację regionalną za nieperspektywiczną ${ }^{164}$. Azerscy komentatorzy też są pesymistyczni. Politolog Zaur Gasimov uważa, że od czterech lat GUAM przypomina raczej WNP. Spotkania na różnych szczeblach są bezskuteczne, bo elity poszczególnych członków tej wspólnoty mają różne interesy. Najważniejsze aspekty GUAM - demokratyzacja i integracja z NATO - nie są już kwestiami priorytetowymi dla elit w Kijowie, Kiszyniowie ${ }^{165} \mathrm{czy} \mathrm{Baku}^{166}$. Zdaniem

159 Cyt. za V. Dunaeva, op. cit., s. 80.

160 D. Kałan, op. cit. Jak było wcześniej wykazane w tekście, kwestie energetyczne przewartościowały jego politykę i posunięcia.

161 A. Myśliwy, op. cit., s. 140.

162 Ibidem, s. 141.

163 V. Dunaeva, op. cit., s. 78.

164 A. Lemieszonek, op. cit.

165 Mołdawia opowiadała się za integracją z UE.

166 Azerbejdżan będzie drugim Iranem (wywiad z dr. Zaurem Gasimovem 29 I 2011), http://www. portal.arcana.pl/Gasimov-azerbejdzan-będzie-drugim-iranem,598.html (dostęp 14 IV 2012). 
innego azerskiego eksperta Arifa Janusowa GUAM będzie się umacniał, dopóki Rosja „odstrasza sąsiadów (...) agresywną retoryka, dążeniem do odbudowy swych wpływów i ograniczeniem procesów demokratycznych"167. Prognozy i rzeczywistość nie rokują najlepiej tej organizacji.

\section{GU(U)AM - from declarations to reality}

The aim of the lecture is to outline the functioning of GUUAM, the organization which originated in 1997 and associates Georgia, Ukraine, Uzbekistan (until 2005), and Moldova. The author's intention was to answer several vital questions - was it possible to accomplish the desired long-term goals of the member states aiming at limiting the influence of Russia in the region and declaring the intention to join the European Union and NATO? Was it possible to accomplish the declared, common strategic interests such as regulation of region destibilizing conflicts, accomplishment of common economic goals, deepening cooperation in power engineering industry, cooperation in military activities through an organization uniting countries on such diversified levels of political transformation, with poorly functioning economies inherited after the Soviet Union, and Russian military bases on their territories? The author identifies entities that really care for GUUAM's survival and its further dynamic actions. She also poses questions on future prospects of development of this organization, trying to find the answer to the question why Poland has so much engaged on behalf of GUAM.

\section{ГУ(У)АМ - от декларации по действительность}

Целью статьи является начертать функционирования организации ГУАМ, объединяющей с 1997 г. Грузию, Украину, Узбекистан (официально вышел из членства в 2005) Молдавию. Автор хотела ответить на несколько важных вопросов - удалось ли реализовать декларированные совместные долгосрочные цели государств-членов, стремящихся к ограничению влияния России в регионе и декларирующих вступление в Европейский союз и НАТО? Возможно ли реализовать заявленные совместные стратегические интересы (регулировать конфликты дестабилизирующие регион, совместные экономические цели, углубление энергетического сотрудничества, кооперация в военной сфере) организацией, объединяющей государства на так разном уровне политических преобразований, имеющие экономику не в наилучшем состоянии (унаследованную после СССР), а также российские военные базы на своей территории? Автор показывает кто заинтересован в сохранении и динамичной деятельности ГУАМ. Она задумывается о том, каковы дальнейшие перспективы развития этой организации? Автор также пытается ответить на вопрос почему Польша ангажируется на стороне ГУАМ. В заключении она приходить к выводу, что организация действует благодаря вовлечению разных актеров в получение доступа к источникам энергии и независимости от поставок из России. Однако проводимая энергетическая политика - непредсказуема, так же как и будущее этой организации.

167 „Niezawisimaja Gazeta” - GUAM chce zostać unijna dyspozytornia gazu... 